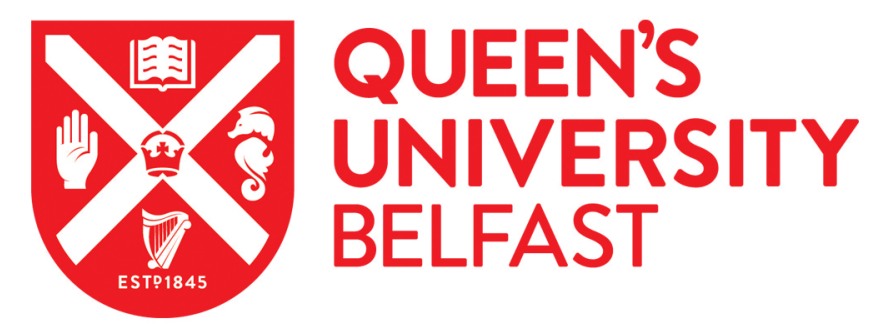

\title{
The performance of concrete exposed to marine environments: predictive modelling and use of laboratory/on site test methods
}

Nanukuttan, S. V., Basheer, P. A. M., McCarter, W. J., Tang, L., Holmes, N., Chrisp, T. M., Starrs, G., \& Magee, B. (2015). The performance of concrete exposed to marine environments: predictive modelling and use of laboratory/on site test methods. Construction and Building Materials, 93, 831-840. https://doi.org/10.1016/j.conbuildmat.2015.05.083

Published in:

Construction and Building Materials

Document Version:

Peer reviewed version

Queen's University Belfast - Research Portal:

Link to publication record in Queen's University Belfast Research Portal

Publisher rights

(c) 2015, Elsevier. Licensed under the Creative Commons Attribution-NonCommercial-NoDerivatives 4.0 International

$\mathrm{http}: / /$ creativecommons.org/licenses/by-nc-nd/4.0/ which permits distribution and reproduction for non-commercial purposes, provided the author and source are cited.

\section{General rights}

Copyright for the publications made accessible via the Queen's University Belfast Research Portal is retained by the author(s) and / or other copyright owners and it is a condition of accessing these publications that users recognise and abide by the legal requirements associated with these rights.

Take down policy

The Research Portal is Queen's institutional repository that provides access to Queen's research output. Every effort has been made to ensure that content in the Research Portal does not infringe any person's rights, or applicable UK laws. If you discover content in the Research Portal that you believe breaches copyright or violates any law, please contact openaccess@qub.ac.uk. 


\title{
The performance of concrete exposed to marine environments: predictive modelling and use of laboratory/on site test methods
}

\author{
S. V. Nanukuttan ${ }^{1 *}$, P.A.M. Basheer ${ }^{2}$, W. J. McCarter ${ }^{3}$, L. Tang ${ }^{4}$, N. Holmes ${ }^{5}$, T. M. Chrisp ${ }^{3}$, \\ G. Starrs ${ }^{3}$ and B. Magee ${ }^{6}$ \\ 1* School of Planning, Architecture and Civil Engineering, Queen's University Belfast, Belfast, UK \\ 2 School of Civil Engineering, University of Leeds, England, UK
}

3 School of Energy, Geoscience, Infrastructure and Environment, Heriot Watt University, Edinburgh, UK

4 Chalmers University of Technology, Gothenburg, Sweden

5 School of Civil and Structural Engineering, Dublin Institute of Technology, Dublin, Ireland

6 School of the Built Environment, University of Ulster, Newtownabbey, UK

\begin{abstract}
This paper reports an approach by which laboratory based testing and numerical modelling can be combined to predict the long term performance of a range of concretes exposed to marine environments. Firstly, a critical review of the test methods for assessing the chloride penetration resistance of concrete is given. The repeatability of the different test results is also included. In addition to the test methods, a numerical simulation model is used to explore the test data further to obtain long-term chloride ingress trends. The combined use of testing and modelling is validated with the help of long-term chloride ingress data from a North Sea exposure site. In summary, the paper outlines a methodology for determining the long term performance of concrete in marine environments.
\end{abstract}

KEYWORDS: Chloride Ingress, Chloride Diffusivity, Electrical Resistivity, Concrete Testing, Chloride Modelling, Permit Ion Migration Test, Charge Passed, Performance Testing, Performance-based Specification

\section{INTRODUCTION}

Premature deterioration of reinforced concrete structures due to lack of durability and subsequent poor state of their health, has led to a significant part of the construction budget 
being spent on repair and rehabilitation works. As a direct consequence, asset owners are often forced to take decisions to repair and maintain existing ailing infrastructure, as opposed to investing in new ones. Effective decision making in this regard requires systematic information about the state of health of an asset (or expected performance), an acceptable level of variance in this information and an effective maintenance strategy that is linked to its whole life value. In the case of concrete infrastructure, factors such as, for example, materials used, design and type of loading on the structure, its location and severity of the exposure condition, will all influence the decision making process as to the calculated state of health of the structure.

It is important, therefore, to specify the expected performance of a structure in addition to the guidelines given in standards, such as BS 8500, which detail the factors defined above. Some of the leading European and International research organisations such as RILEM Technical Committee 230-PSC, fib Task Group 8.10 and ACI Committee 365 are focusing on developing "Performance-based Specification for concrete". The final technical report by Brite EuRam III DuraCrete [1] project provides an insight into the future of such specifications. Further articles on this topic can be found elsewhere [see, for example, 2-5]. As the quality of materials and exposure environments vary for different countries, it is also necessary to develop and refine the specifications so that they remain relevant to the practices of that country. The availability of test methods and understanding in the use of predictive models will also become critical in the general adoption of performance-based specification.

This paper details an approach by which laboratory and on site (in situ) testing can be further exploited with the help of a numerical model in order to determining the long term performance of concrete exposed to marine environments. The data presented in this paper are obtained from three research projects:

1) ChlorTest supported by European Union, Framework 5 [6];

2) $\mathrm{PhD}$ research by one of the authors (S.V. Nanukuttan) [7], and

3) Performance-based Testing Methodologies supported by Engineering Physical Science Research Council [8].

A range of test methods available for assessing the resistance to chloride ingress are reviewed and their repeatability compared. Numerical simulation of chloride movement into concrete is undertaken using a service life prediction model and the simulated data compared with on site 
data obtained from a long-term marine exposure study. The main objective of this paper is to present and summarise developments in testing and modelling of concrete for chloride ingress and to illustrate how progress could be made in developing performance-based specifications.

\section{MEASUREMENT OF RESISTANCE TO CHLORIDE INGRESS IN CONCRETE}

Although the primary mechanism of chloride transport through unsaturated concrete cover is absorption, the accumulation of chlorides in this layer leads to further penetration of chlorides into the cover-zone by diffusion [9]. As a consequence, diffusion becomes the dominant mechanism of chloride transport at greater depths, which can be assessed in terms of the diffusion coefficient of the chloride ion. Different test methods are available to determine the diffusion coefficient, e.g. steady-state and non-steady-state chloride diffusion. As diffusion takes time to establish and tests are often tedious, migration tests are often used to quantify the movement of chlorides in concrete. The most common migration test uses an external electrical field to accelerate the flow of chloride ions, hence the coefficient determined using such a test is termed a migration coefficient. In addition, diffusivity is recognised as a term that represents chloride transport resistance of concrete, irrespective of the mechanism used to establish the flow of chlorides.

\subsection{Experimental programme}

Table 1 shows mix details of 9 typical concretes used across Europe. The concrete samples (large slabs) were cast as part of the EU funded ChlorTest programme[6]. Cores of $100 \mathrm{~mm}$ diameter and $200 \mathrm{~mm}$ length were extracted from the samples and these were transported to Queen's University in a moist state and were kept at $20^{\circ} \mathrm{C}$ until the test date. Samples were wrapped with moist hessian to prevent drying. All data reported in Table 1 were generated by the tests carried out at Queen's University. In addition to the mix design, the table also shows migration and electrical resistivity data from NT Build 443[10], NT Build 492[11] and bulk electrical resistivity [12] testing. Average chloride concentration at depths $5 \mathrm{~mm}$ and $10 \mathrm{~mm}$ from the surface from samples studied for NT Build 443[10] are also reported. Repeatability of the tests are discussed together with the long-term performance (readers interested in reproducibility of the tests may refer to ChlorTest[6] report where inter and intra laboratory comparisons were analysed). 
Table 1 Details of concrete mixes (Quantities reported in $\mathrm{kg} / \mathrm{m}^{3}$ ) and their chloride ingress resistance as measured by different test methods

2.2 Relationship between chloride penetration and concrete diffusivity assessed using different lab based test methods

Figs. 1 to 3 present the diffusivity of concrete (assessed using different laboratory-based tests) plotted against the quantity of chloride ions measured at 5 and $10 \mathrm{~mm}$ depths from the exposed surface. The chloride ion concentration at these depths was determined by the potentiometric titration method using powder samples collected from concrete specimen immersed in $2.8 \mathrm{M} \mathrm{NaCl}$ solution for 35days. Data points represent nine different concrete mixes and the test age of concrete samples was >180days. Results presented in Figs. 1 to 3 indicate that the diffusivity assessed by the different test methods can be used with varying degree of accuracy to predict the chloride concentration at a particular depth.

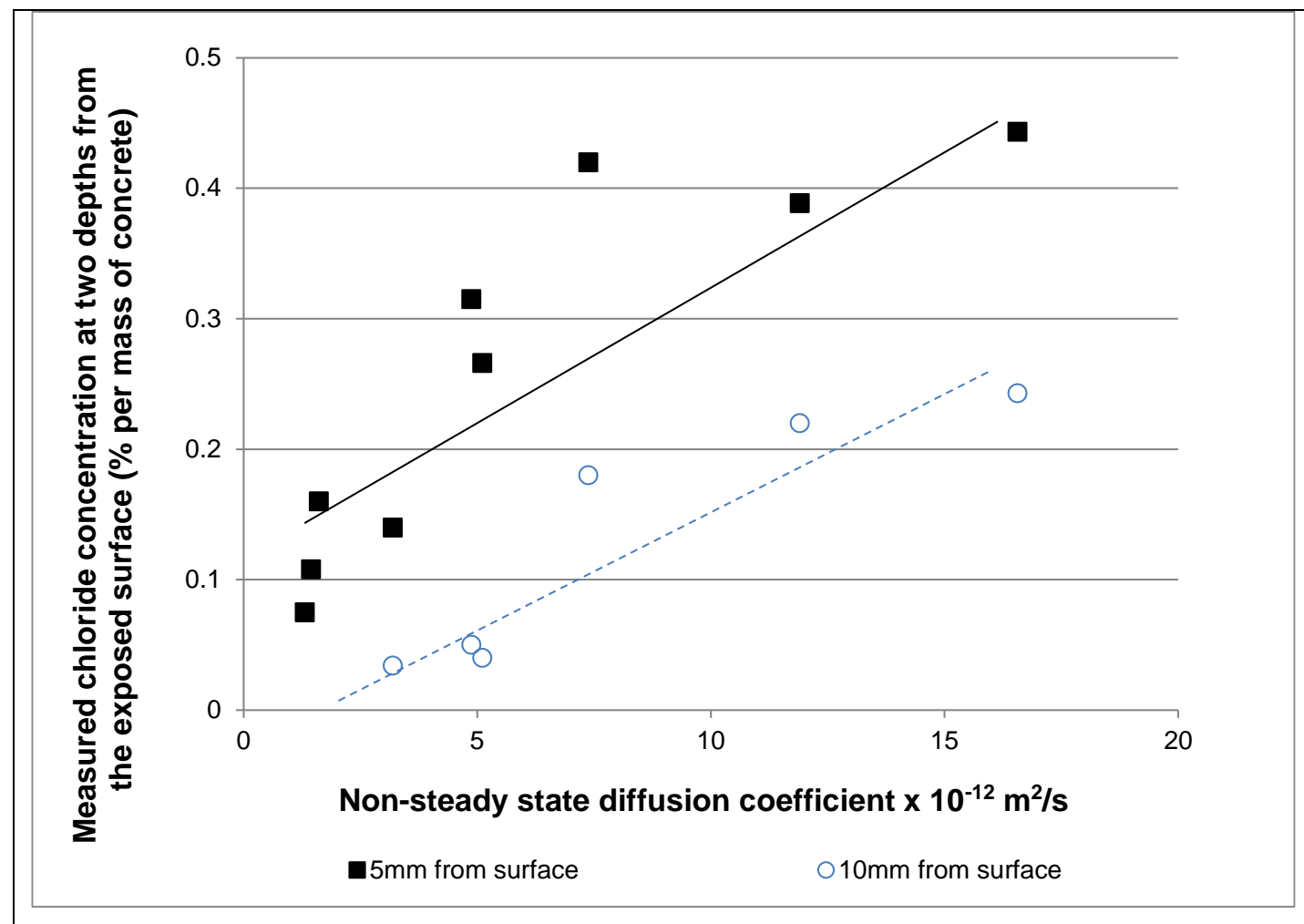

Fig. 1 - Concentration of chloride ions versus non-steady state diffusion coefficient ( $\left.\mathrm{D}_{\text {nssd }}\right)$ determined using NT Build 443[10] for 5mm and 10mm depths from the exposed face of concrete specimens.

Note: Age of testing is $>180$ days, Each data point represent a concrete mix refer to Table 


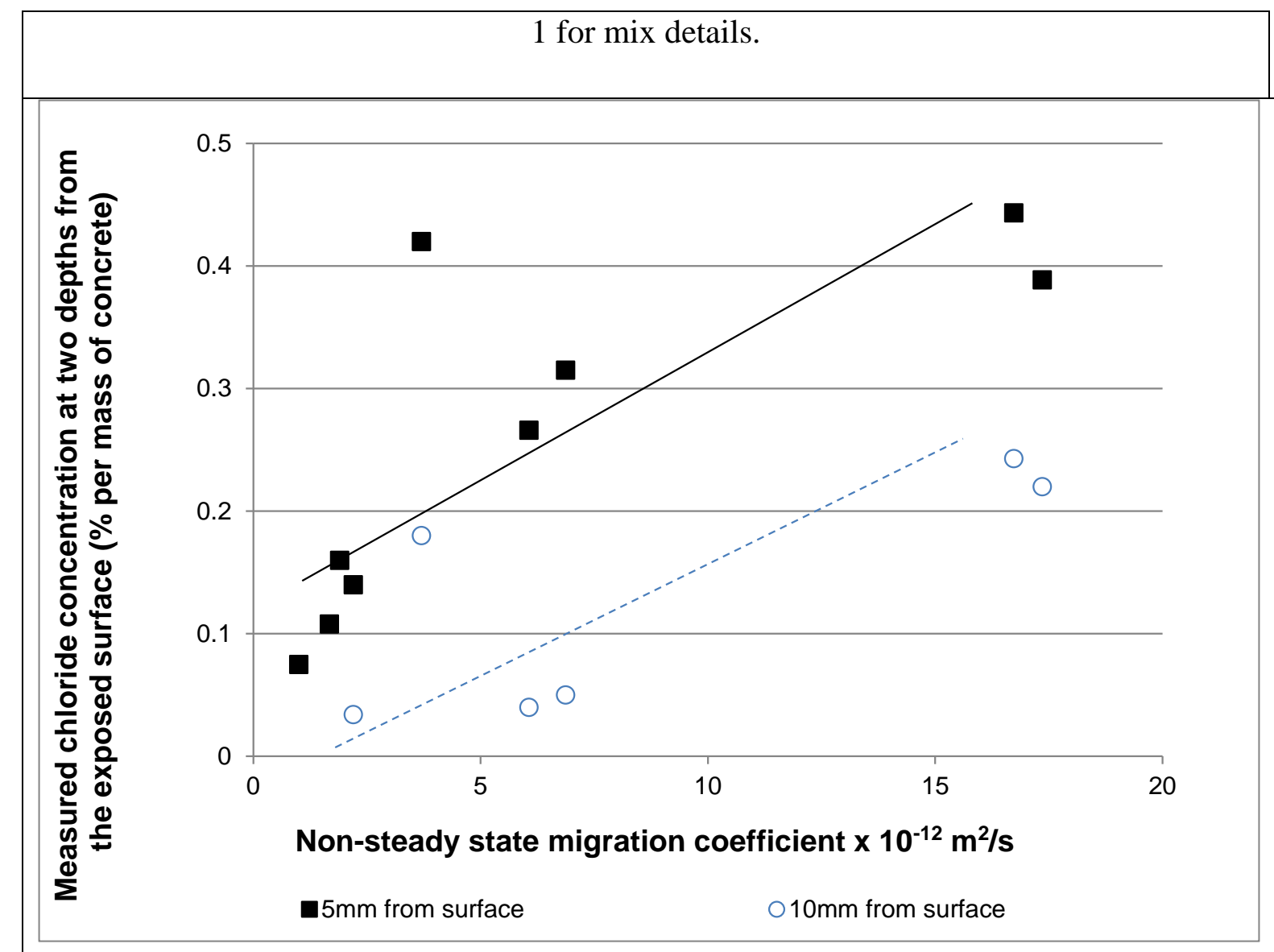

Fig. 2 - Concentration of chloride ions versus non-steady state migration coefficient $\left(D_{n s s m}\right)$ for depths $5 \mathrm{~mm}$ and $10 \mathrm{~mm}$ from the exposed face of concrete specimens (obtained from Nordtest NT Build 492 [11]).

Note: Age of testing is $>180$ days, Each data point represent a concrete mix refer to Table 1 for mix details.

Figs. 2 and 3 suggest that useful information about the penetration of chloride ions can be obtained using rapid test methods. NT Build 492 [11] requires, on average, 24 hours to assess the diffusivity of concrete whereas electrical resistivity can be measured instantaneously. It is also worth noting that the electrical resistivity, in this case, was obtained from concrete specimens saturated with calcium hydroxide $\left(\mathrm{Ca}(\mathrm{OH})_{2}\right)$ solution. The procedure for carrying out the test can be found in references [12] and [6]. All these tests require concrete cores with a minimum thickness $50 \mathrm{~mm}$ to be extracted from the structure which considerably limits the number of test that can be performed as frequent testing can leave the structure badly 
disfigured. As a result, two on site methods were also included as part of this study which are outlined in the next section.

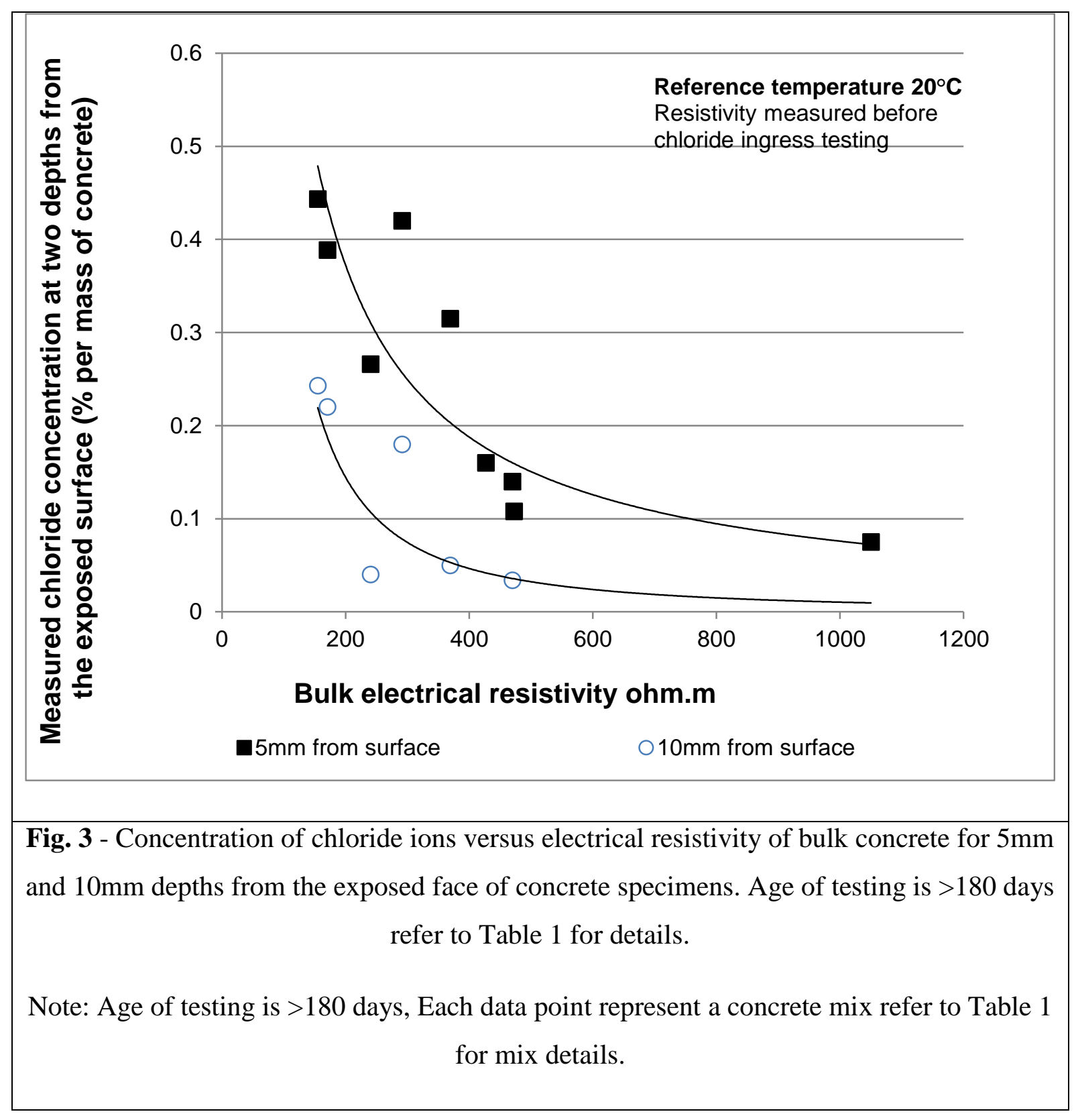

\section{ONSITE METHODS FOR ASSESSING CHLORIDE DIFFUSIVITY}

\section{$\underline{3.1 \quad \text { Background of Permit Ion Migration Test (Permit) }}$}

This is a unique, non-destructive, surface-based test developed on the principles of the steady state migration test. Initial developments of this test are detailed elsewhere [14] and further refinements during 2007-10 resulted in automation of the procedure and making it site/user 
friendly [7]. The test apparatus is shown in Fig. 4a. and a brief description of the apparatus and working principle are outlined below for the benefit of readers.

The Permit comprises two concentric cylinders placed on the concrete surface with the inner cylinder and outer cylinder containing $0.55 \mathrm{M} \mathrm{NaCl}$ and de-ionised water, respectively. $\mathrm{A}$ potential difference is applied via a stainless steel cathode placed in the inner cylinder and mild steel anode placed in the outer cylinder. The test establishes a flow of chloride ions from inner cylinder through concrete to the outer cylinder. A conductivity sensor located in the outer cell monitors the conductivity of the electrolyte (initially de-ionised water) and this is converted to chloride concentration using relationship established by Castellote et al., [13]. The validity of conductivity/concentration relationship was established for the range of concretes using the Permit and is shown in Fig. 4b. The change in conductivity (therefore concentration) is used in the Nernst-Planck equation to obtain a migration coefficient ( $\mathrm{D}_{\text {in situ }}$ ) viz,

$$
D_{\text {insitu }}=-\left(\frac{d c}{d t} \frac{T}{E}\right)\left(\frac{R}{z C F}\right)\left(\frac{L}{A} V\right) \quad \text { Eq. } 1
$$

Where,

$$
\begin{array}{lll}
D_{\text {in situ }} & =\text { migration coefficient, } \mathrm{m}^{2} / \mathrm{s} \\
\frac{d c}{d t} & = & \text { rate of change of concentration in the anolyte, } \mathrm{mol} / \mathrm{m}^{3} . \mathrm{s} \\
T & = & \text { absolute temperature (average during the steady state) } \mathrm{K} \\
R & =\quad \text { universal gas constant }(8.31 \mathrm{~J} / \mathrm{K} \cdot \mathrm{mol}) \\
z & =\quad \text { valency of the ions }(-1 \text { for chlorides }) \\
C & =\quad \text { Faraday's Constant }\left(9.65 \times 10^{4} \mathrm{c} / \mathrm{mol}\right) \\
F & =\quad \text { electrical potential applied between the anode and the cathode }(15, \\
E & =\quad \text { volume of the anolyte }\left(6.5 \times 10^{-4} \mathrm{~m}^{3}\right)
\end{array}
$$


L/A $=$ ratio of the flow length to the exposed area $\left(3.74 \mathrm{~m}^{-1}\right)$

In addition to conductivity, the Permit also monitors the current (therefore charge passed) and temperature. A typical set of data from the Permit is presented in Figs. 4c and 4d. The reliability of the test was established by correlating the results with those obtained from other commonly used diffusion/migration test methods.

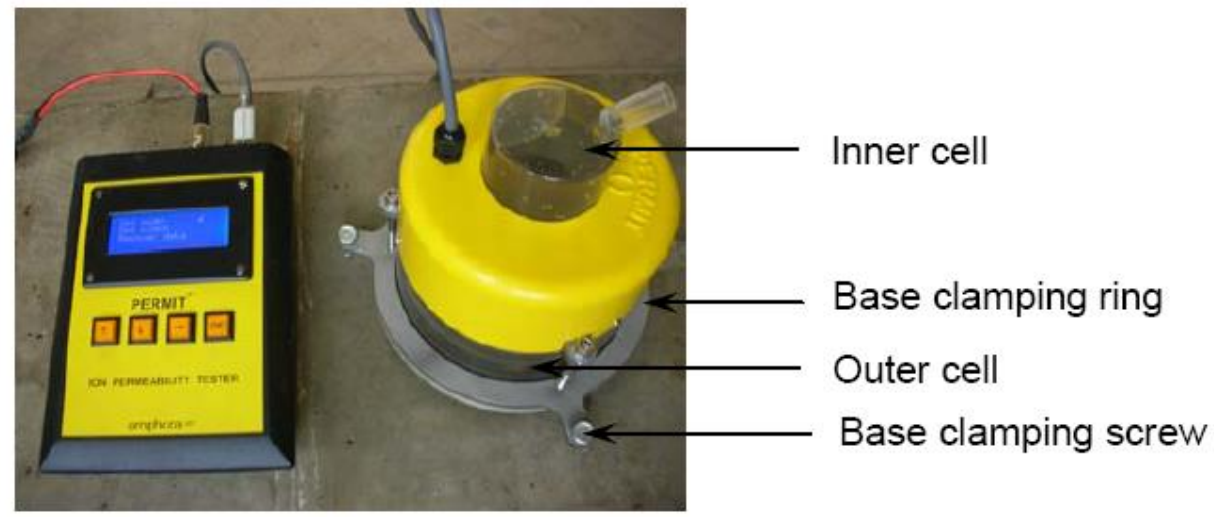

Fig. 4a - The Permit Ion Permeability Tester (controller and the main body)

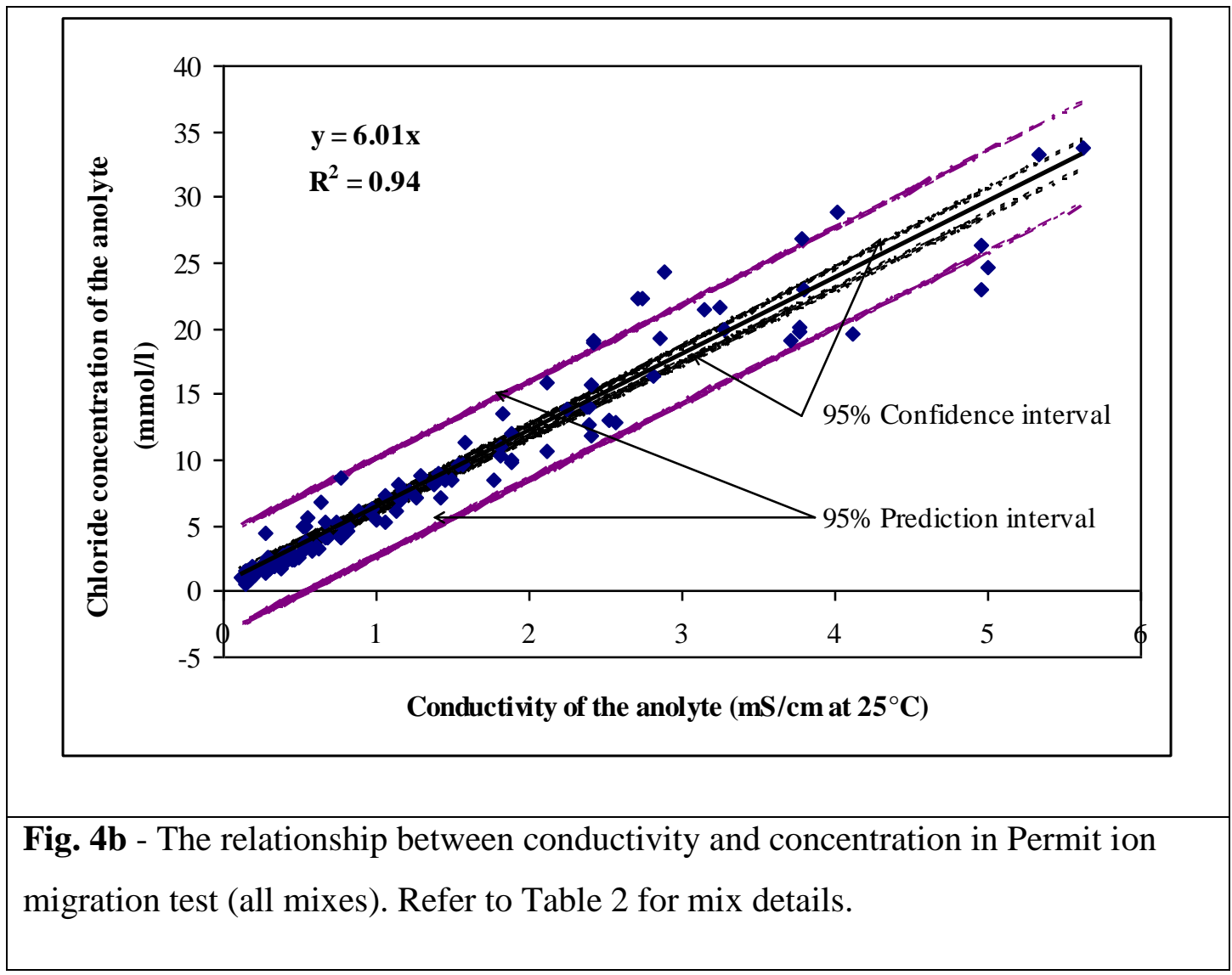



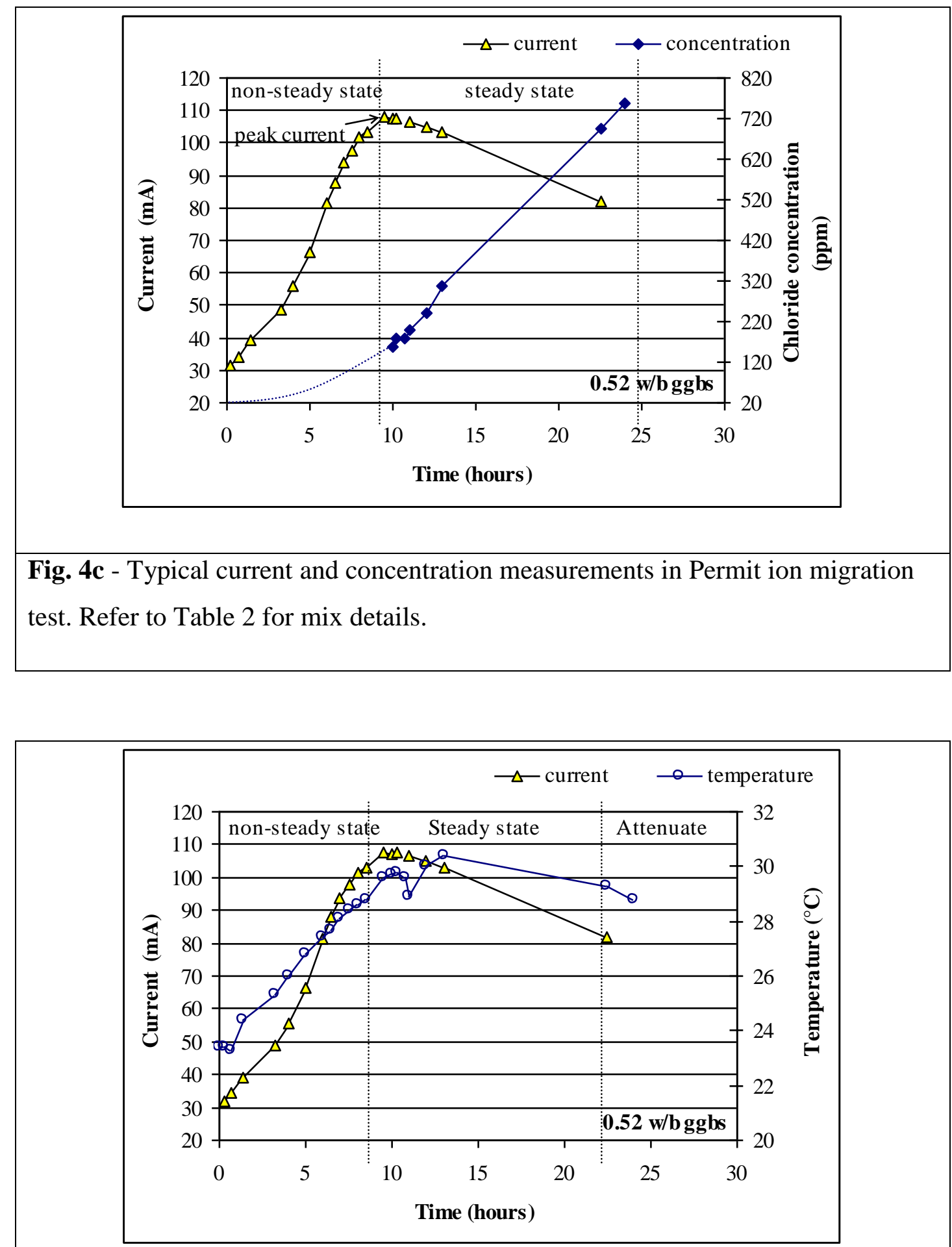

Fig. 4d - Typical temperature and current measurement in Permit ion migration test. Refer to Table 2 for mix details.

\section{$\underline{3.2 \quad \mathrm{D}_{\text {in situ }} \text { and other measures of chloride transport }}$}

The objectives of this study were to establish: 
(1) the validity of $D_{\text {in situ }}$ in assessing diffusivity for a range of concretes;

(2) the effect of supplementary cementitious materials on $\mathrm{D}_{\text {in situ }}$; and,

(3) the usefulness of current and charge passed as a measure of chloride diffusivity.

Eight concrete mixes containing Portland cement (CEM I), pulverised fuel ash (pfa), ground granulated blast-furnace slag (ggbs) and microsilica (ms) were used. Details of the mix design, test age are presented in Table 2.

Table 2. Details of mixes used in this experimental programme

\subsubsection{Relationship between $\mathrm{D}_{\text {in situ }}$ and steady state migration coefficient}

A typical steady state migration test was carried out in this investigation that resembles the test proposed by Castellote [13]. The only deviation was that the concentration of catholyte $(\mathrm{NaCl})$ solution was $0.55 \mathrm{M}$ instead of $1.0 \mathrm{M}$. The relationship between $\mathrm{D}_{\text {in }}$ situ and the coefficient determined using the steady state migration test is presented in Fig. 5. There is a high degree of correlation between the two migration tests $\left(\mathrm{R}^{2}=0.93\right)$, showing that the chloride diffusivity determined with the Permit ion migration test is as accurate as the more established steady state migration test. Basheer et al., [14] reported similar result for CEM I cement mixes and the results in Fig. 5 are for mixes containing a range of different cementitious materials. It can be concluded, therefore, that the Permit ion migration test can be used to determine the chloride diffusivity irrespective of the binder type in concretes. Moreover, the $\mathrm{D}_{\text {in situ }}$ values were determined within 1 day compared to 7 days required for determining the steady state migration coefficient. 


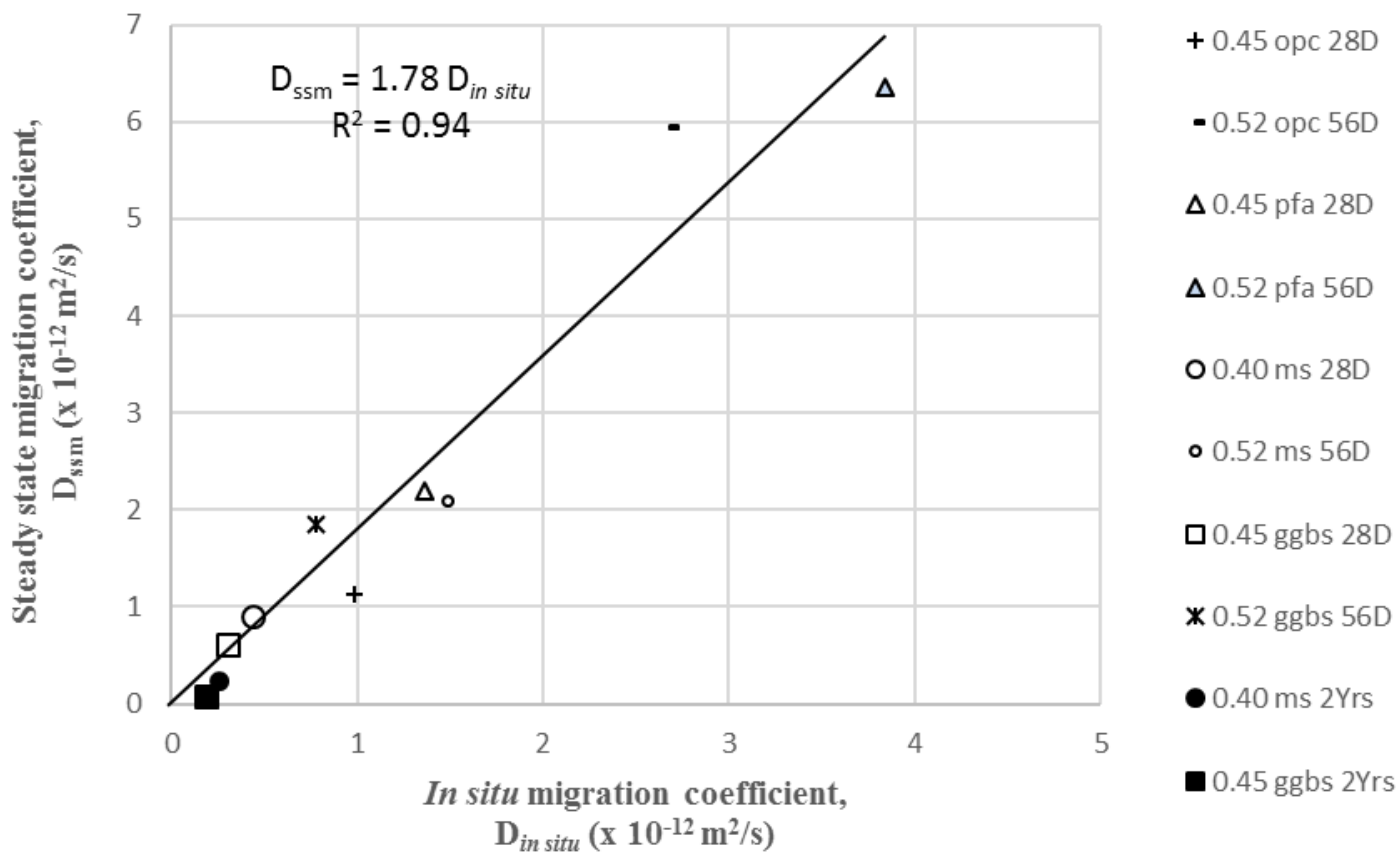

Fig. 5 - Graph demonstrating the usefulness of $D_{\text {in }}$ situ in determining the steady state migration coefficient. (Legend shows, mix reference as in Table $2+$ age of concrete at test, Example: 0.45 opc $28 \mathrm{D}-0.45 \mathrm{w} / \mathrm{b}$ opc as in Table 2 tested at 28 days).

\section{$\underline{\text { 3.2.2 Relationship between } \mathrm{D}_{\text {in }} \text { situ } \text { and non-steady state migration coefficient }}$}

NT Build 492 test is commonly used by the industry to quantify diffusivity, therefore $\mathrm{D}_{\mathrm{nssm}}$ obtained from this test was compared with $\mathrm{D}_{\text {in situ. }}$ Fig. 6 shows that these two parameters have a linear relationship $\left(\mathrm{R}^{2}=0.85\right)$. Several factors are known to influence the relationship between a steady state and a non-steady state test result. This can be explained with the equation suggested by Nilsson et. al., [9]:

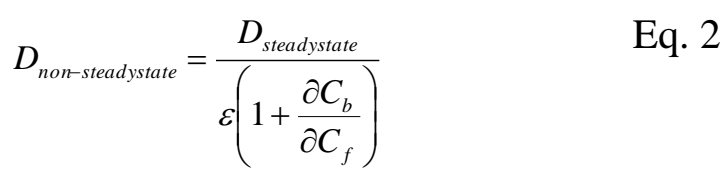

Where $\varepsilon$ is the porosity and $\frac{\partial C_{b}}{\partial C_{f}}$ the binding capacity of concrete.

This would imply that the relationship will be affected by both binding capacity and porosity and hence a larger scatter will be expected if experiment is repeated with different binder contents, type of binder or water-binder ratio. 


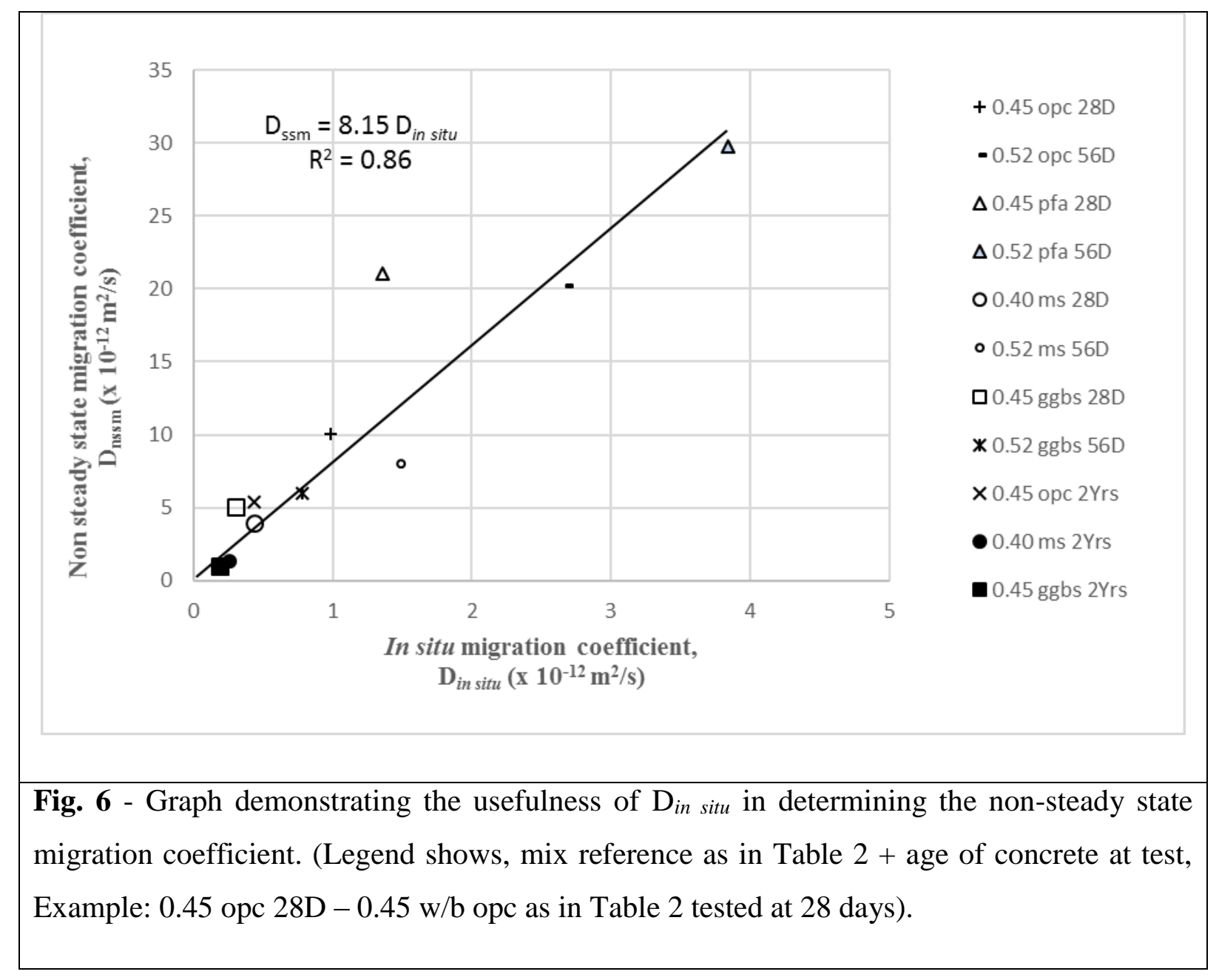

\section{$\underline{\text { 3.2.3 Effect of type of binder and } \mathrm{w} / \mathrm{b} \text { on } \mathrm{D}_{\text {in situ }}}$}

The results indicate that $\mathrm{D}_{\text {in situ }}$ is sensitive to both binder type and w/b as shown in Fig. 7. The use of supplementary cementitious materials generally decreased the $\mathrm{D}_{\text {in }}$ situ at both w/b ratios investigated. Whereas ggbs and ms mixes exhibit the lowest $\mathrm{D}_{\text {in situ }}$, the pfa mixes had the highest $\mathrm{D}_{\text {in situ. }}$. This could be due to the slow initial hydration of pfa particles. The trend shown in Fig. 7 is similar to that observed by Basheer et al., [14]. Therefore, it can be stated that the $\mathrm{D}_{\text {in situ }}$ was able to distinguish the variations in the mixes and in a manner similar to that by most migration tests. 


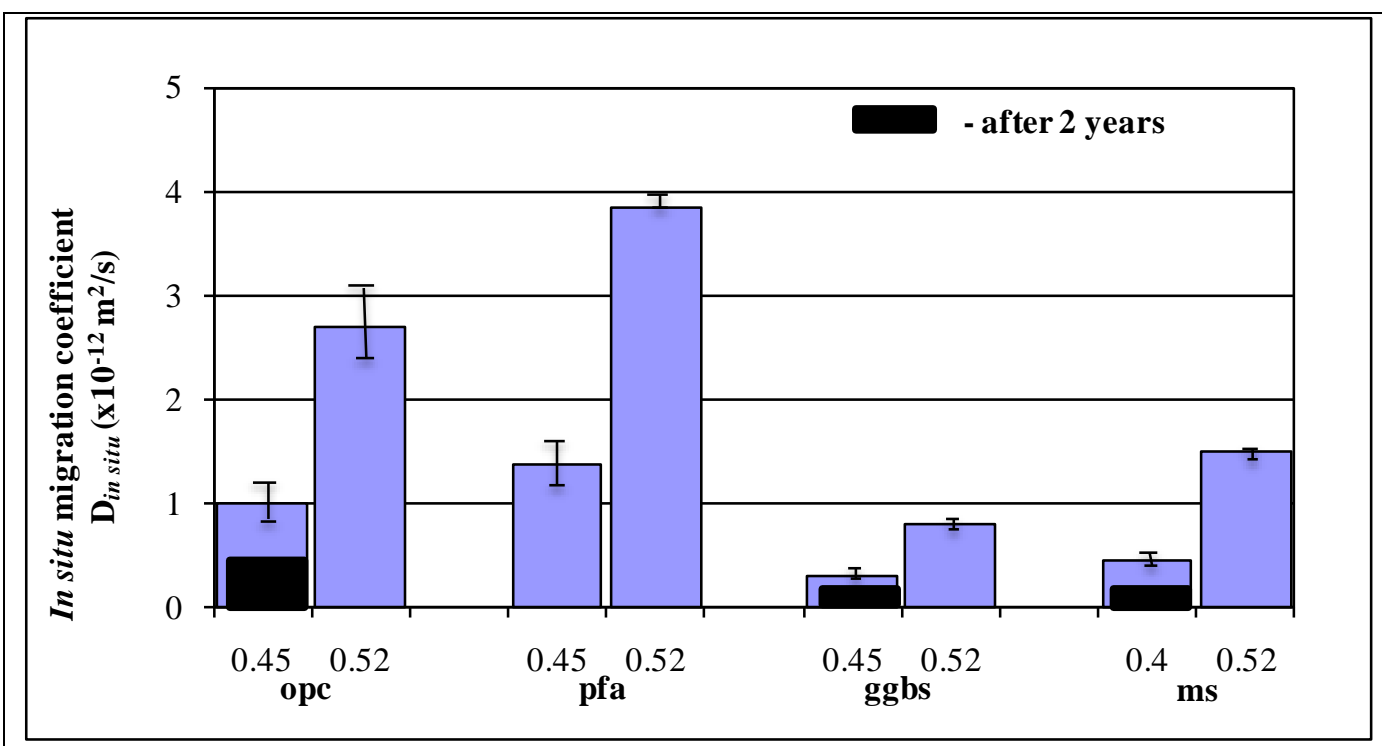

Fig. 7 - The effect of mix properties on the in situ migration coefficient, $\mathrm{D}_{\text {in situ }}$

\subsection{Peak current, charge passed and chloride diffusivity}

In addition to estimating conductivity (concentration), the Permit also monitors the current and temperature evolution. Current evolution follows an unusual behavior as shown in Fig. 4c. In order to further explore this behaviour, the peak value of the current was compared to that of $\mathrm{D}_{\text {in situ. }}$

3.3.1 Relationship between $\mathrm{D}_{\text {in situ }}$ and the peak current- Fig. 8 shows that the relationship between $\mathrm{D}_{\text {in situ }}$ and the peak current is linear with a coefficient of regression of $\mathrm{R}^{2}=0.82$. As shown in Fig. 4c, the peak value of the current is obtained when the flow of chloride ions reach steady state. Therefore it should be is possible to determine the diffusivity with the help of transference number and Nernst-Einstein equation as explained by Andrade [15]. This is outside the scope of this paper and will not be discussed.

3.3.2 Relationship between $\mathrm{D}_{\text {in situ }}$ and the charge passed- There is no apparent relationship between $\mathrm{D}_{\text {in situ }}$ and charge passed for the first 6 hours as seen in Fig. 9. This is to be expected as all ions present in the surface concrete will be taking part in the charge transfer process therefore attributing this to just chloride ions is not correct. The relationship improves marginally when the charge passed until steady state is compared to that of $\mathrm{D}_{\text {in situ }}$ (refer to Fig. 10). 
As the flow reaches steady state in a migration test, the current approaches its peak value, therefore the charge passed during the steady state will have a better relationship with chloride flow. To study this further, the rate of change of charge passed (average current) during steady state was plotted against the rate of change of chloride concentration, the result is presented in Fig. 11.

The regression relationship in Fig. 11 is represented by Eq. 3, with a regression coefficient $\left(\mathrm{R}^{2}\right)$ of 0.85 .

$$
\frac{d Q}{d t}=210.81 \frac{d c}{d t}
$$

where

$\frac{d Q}{d t}$ is the rate of change of charge during the steady state, coulombs/s,

$\frac{d c}{d t}$ is the rate of change of chloride concentration during the steady state, $\mathrm{mol} / \mathrm{m}^{3} . \mathrm{s}$,

Equation 3 suggests that the rate of change of chloride concentration can be estimated with $85 \%$ confidence using the value of the rate of change of charge. A similar trend was reported by Yang [16], where the author found that the charge passed during steady state flow was more comparable to the chloride penetration resistance of concrete than the first 6 hours charge passed. The implication of this is that by measuring the current, the rate of change of chloride concentration can be estimated in the Permit. Such a change would not only simplify the test procedure, but also reduce the cost of manufacturing the test equipment.

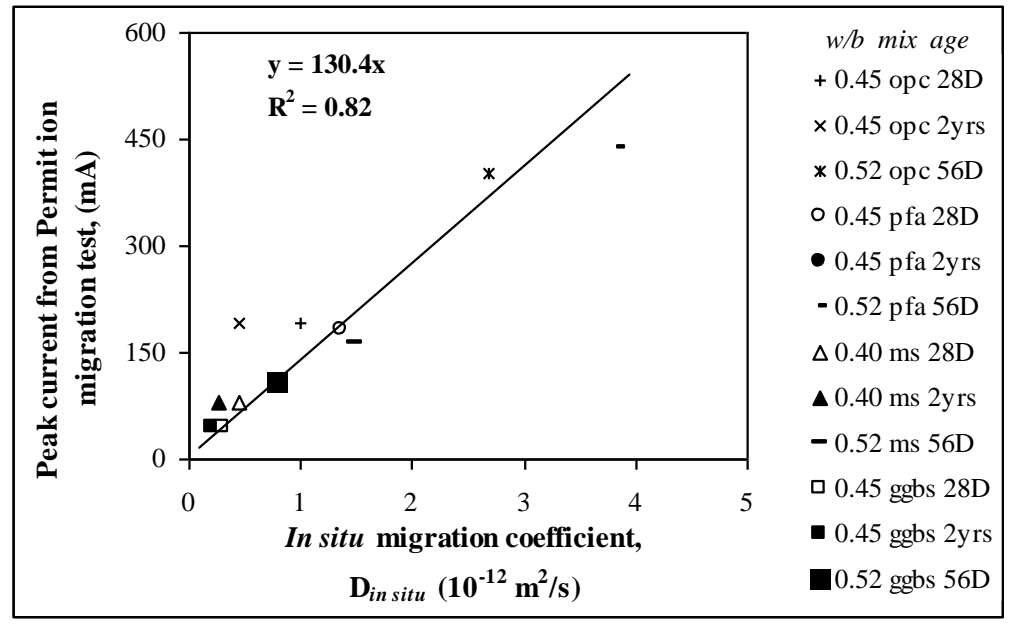


Fig. 8 - Relationship between $D_{\text {in situ }}$ and the peak current in Permit ion migration test

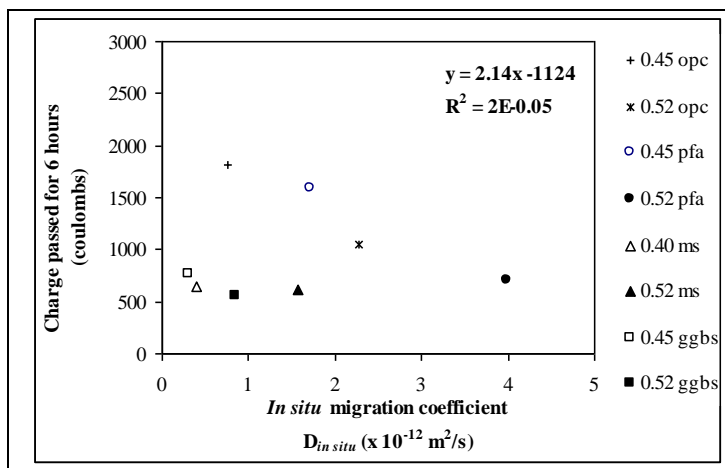

Fig. 9 - Relationship between $D_{\text {in situ }}$ and the charge passed during the initial 6 hours in Permit ion migration test. The graph only reports data from 28 day and 56 day tests.

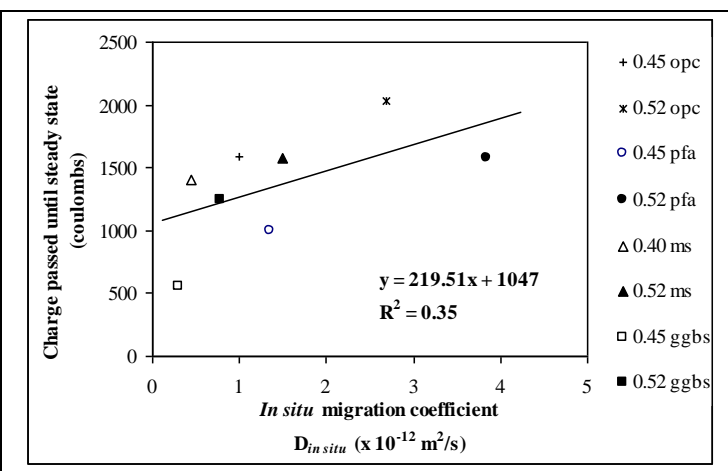

Fig. 10 - Relationship between $\mathrm{D}_{\text {in situ }}$ and the charge passed until steady state in Permit ion migration test. The graph only reports data from 28 day and 56 day tests. 


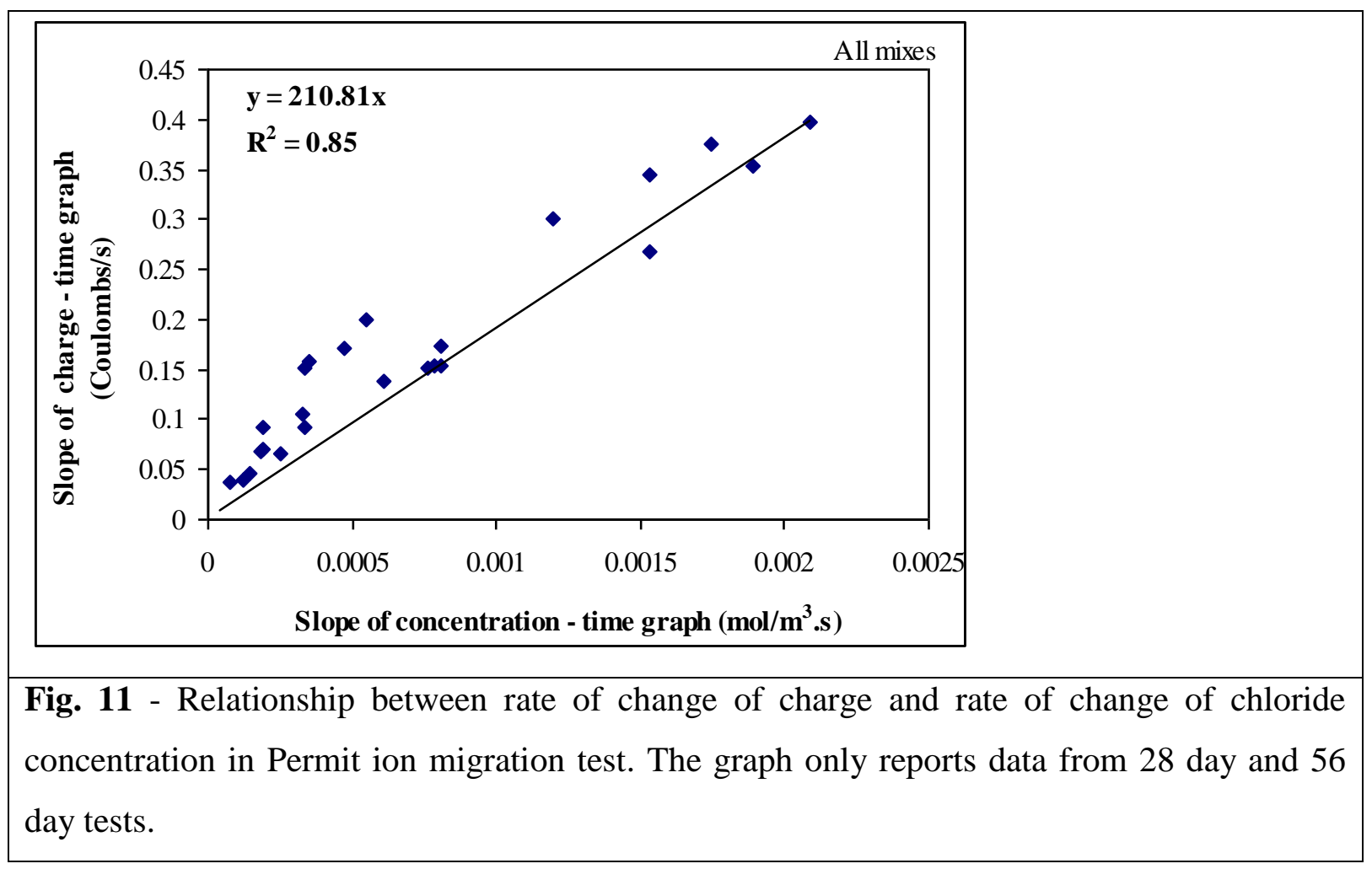

\subsection{Wenner four probe resistivity and chloride diffusivity}

Published literature suggests that resistivity (bulk resistivity) of either water saturated or ionically $\left(\mathrm{NaCl}\right.$ or $\mathrm{Ca}(\mathrm{OH})_{2}$ ) saturated concrete specimens can be used to predict the steady or non-steady state migration coefficients $[12,17]$. In this section the suitability of a surface based electrical resistivity test, i.e., Wenner four probe test is studied for determining the chloride diffusivity. The relationship between steady state migration coefficient and inverse of the Wenner four probe surface resistivity $1000 / \rho_{\text {Wenner }}$ is presented in Fig. 12, which shows a linear relationship between these two test parameters. The relationship is represented by the following equation, with an $\mathrm{R}^{2}$ value of 0.7 :

$$
D_{s s m}=\frac{260}{\rho_{\text {Wenner }}}
$$

Where

$\rho$ Wenner is in ohm.m,

and $\mathrm{D}_{\mathrm{ssm}}$ is in $\mathrm{m}^{2} / \mathrm{s}$ (without the multiplier $10^{-12}$ ). 
The relationship is likely to be affected by the level of contact made by the wooden plugs with concrete surface in Wenner four probe resistivity test. Further, any small defects at the point of contact of the concrete surface and degree of saturation could also affect the resistivity value. If bulk conductivity (inverse of bulk resistivity) is assessed instead of Wenner test, the relationship is highly likely to improve as the resistivity is measured across the whole of the test specimen $[6,12,17]$. In any case, the resistivity will be influenced by the nature of the pore solution [18], therefore saturating the test surface will help to get consistent results.

The relationship between the $\mathrm{D}_{\text {in }}$ situ and the inverse of the Wenner probe resistivity, $1000 / \rho_{\text {Wenner }}$ is presented in Fig. 13. The regression relationship is presented by the following equation:

$$
D_{\text {insitu }}=\frac{140}{\rho_{\text {Wenner }}}
$$

where,

$\mathrm{D}_{\text {in situ }}$ is in $\mathrm{m}^{2} / \mathrm{s}$ (without the multiplier $10^{-12}$ ),

$\rho$ Wenner is in ohm.m.

The coefficient of determination $\mathrm{R}^{2}$ obtained in this case was 0.72 , higher value than that obtained for the relationship in Eq. 4. The limitations discussed in previous section will also affect the relationship with $\mathrm{D}_{\text {in }}$ situ. The improvement is due to the fact that both tests were performed on same concrete samples, i.e., water saturated. With this relationship, end-users will be able to rapidly test the surface of concrete using Wenner test and relate these results that to either a $D_{\text {in situ }}$ or $\mathrm{D}_{\text {ssm }}$ performed on the same concrete. It is necessary, however, to establish this relationship for the concrete being tested as several factors including the pore solution composition, curing and type of aggregate will also affect the relationship. 


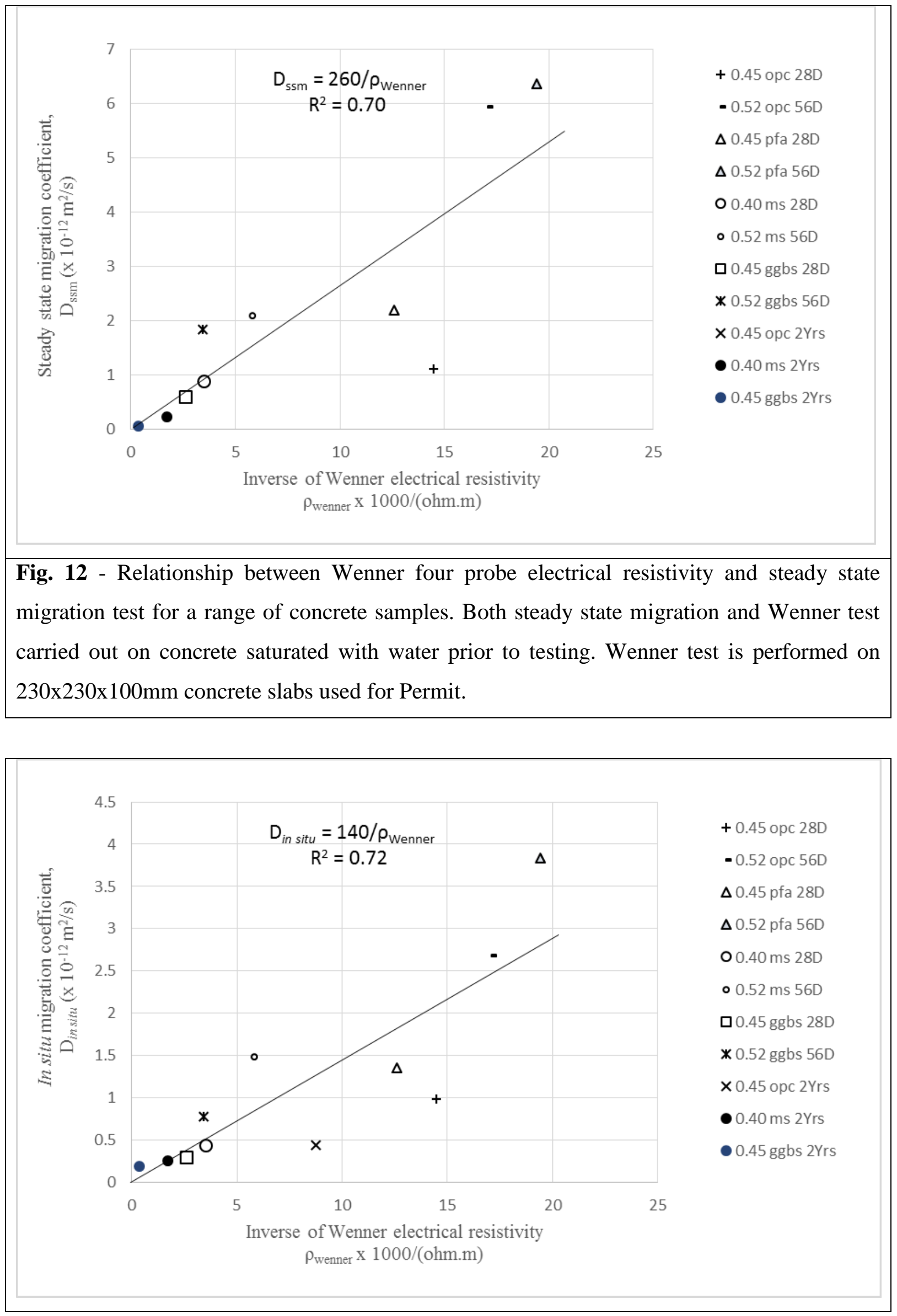


Fig. 13 - Relationship between Wenner four probe electrical resistivity and $D_{\text {in situ }}$ for a range of concrete samples. Both Permit and Wenner test carried out on 230x230x100mm concrete slabs saturated with water prior to testing.

\section{$\underline{3.5 \text { Summary of on site tests for assessing diffusivity }}$}

It was shown that both tests discussed above can quantify diffusivity through their respective parameters. The more rapid $\rho$ wenner is affected by the condition of the test surface and therefore the scatter is large. The scatter expected on site will be greater than that reported in Figs. 12 and 13 due to the uncontrolled nature of test surface. For concretes contaminated with ions, or with different pore solution composition, it would be best to use the Permit or a steady state migration test rather than the electrical resistivity based test.

Results presented in Figs. 5-11 show that the Permit can be used as an alternative to conventional and more commonly used laboratory-based test methods. The following advantages have been identified for the Permit:

a) The test can be performed in situ and there is no need to remove cores for testing.

b) The test procedure is y automated therefore it reduces,

i. human error and does not require a skilled operator to perform the test,

ii. the overall cost of carrying out the test or performance assessment.

c) The test can be performed in combination with the more rapid electrical resistivity test (Figs. 12 and 13) which allows an overall appraisal of the structure within a short period of time, thereby reducing the cost of carrying out condition assessment. This is dealt in detail in the next section.

d) The charge passed obtained by the test during the first 6 hours show no apparent correlation. However, the charge passed during the steady state appears to correlate well with the $D_{\text {in situ. }}$ This is in agreement with results reported elsewhere. Such simplification could provide an alternative way for conducting the test using a more simplified version of the Permit and also help to modify the ASTM C1202 [19] test to yield more reliable coefficient that can represent chloride diffusivity.

\section{EFFECT OF CONCRETE MIX PROPERTIES ON LONG TERM PERFORMANCE}


Several test methods which can assess the resistance of concrete to chloride ingress were identified above. It is important to understand the repeatability and scope of the results in order for the test to be used for qualifying concretes. The results in Table 1 identify the beneficial effects of using supplementary materials, such as pfa, ggbs and ms, and the influence of $\mathrm{w} / \mathrm{b}$ on chloride ingress. Most of the results are, on average, $\pm 20 \%$ from the median, hence it can be concluded that the tests are repeatable with $20 \%$ variability. To study the scope of these results it is necessary either to study the long-term behaviour of these concrete mixes in a field exposure environment or to simulate the behaviour in a given environment. The former would require long-term study with considerable investment and resources, whereas the latter would depend heavily on the accuracy of the numerical model used for predicting the behaviour.

The approach used in this paper is to consider both the aspects. The long-term performance data from a structure exposed to a marine environment (North Sea) is used to validate the numerical model used for prediction. The second aspect is to use the test results in Table 1 along with the validated numerical model to predict the behaviour of different concrete mixes in the same environment.

\subsection{Long-term performance study on concrete specimens exposed to North Sea}

Data from a long-term study conducted on three ordinary Portland cement concrete pier stems exposed to tidal, splash and atmospheric conditions in North Sea are presented below. The concrete mix details are reported in Table 3. Chloride concentrations from various depths (termed as chloride profile) were determined several times for a period up to 7 years and then after 18 years. General location of the piers and annual temperature variation at the site is as shown in Figs. 14 and 15 respectively. Fig. 16 presents the chloride profiles determined after 1.17, 3.17, 6.17 and 18 years exposure and located below mid-tide level - XS2 environment according to [20] (i.e. remaining saturated). Further details on these pier-stems, surface chloride concentrations and chloride profiles are available elsewhere [21], therefore only data relevant to the modelling are detailed here.

Table 3 Mix details and test results for Dornoch pier stems 

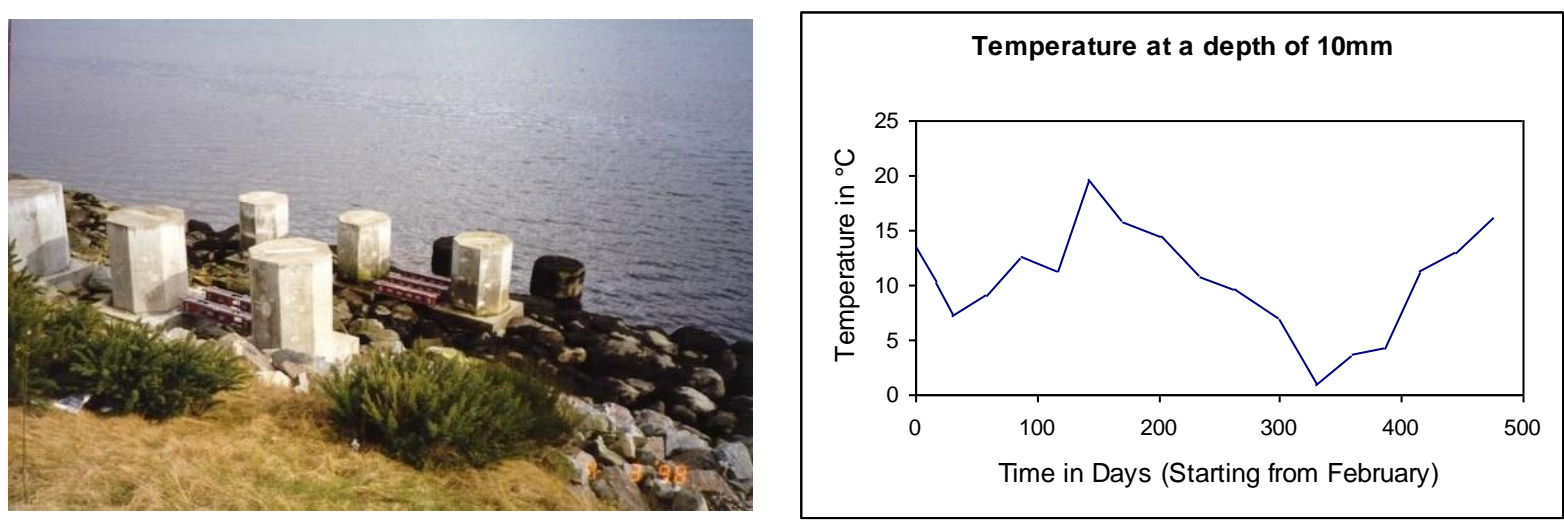

Fig. 14 - Shows the location of the pier stem (right hand side of the picture) near the

Fig. 15 - Temperature of concrete at 10mm depth recorded for 16 months.

Dornoch bridge, Scotland

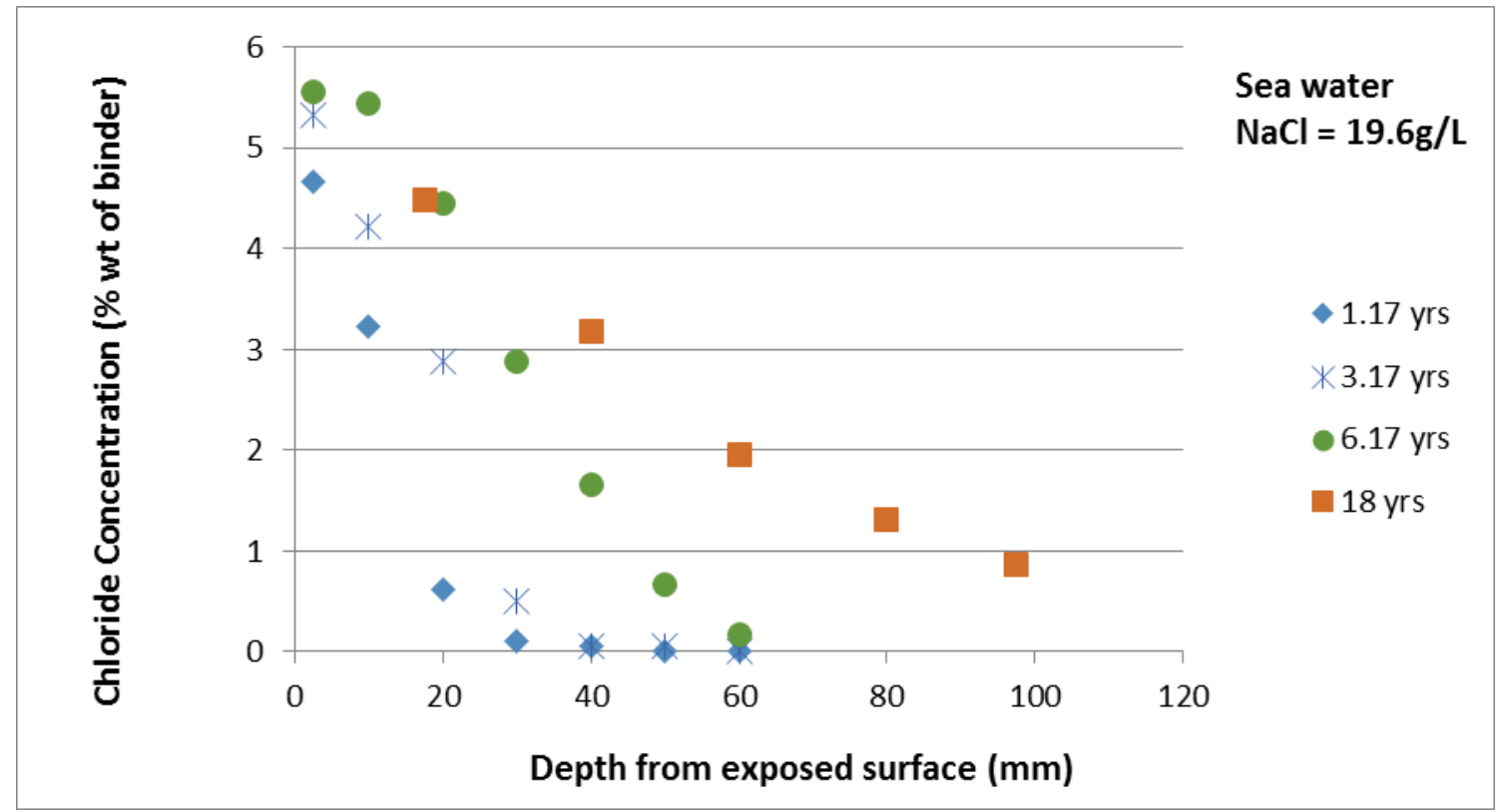

Fig. 16 - The chloride profiles from OPC pier stems exposed to tidal low level

Several service life prediction models were considered as part of the wider study. However, only data from numerical simulations made using ClinConc service life model [22] are reported in this paper as, this model was selected based on the recommendations by the ChlorTest [6] project, which reviewed different test methods and service life models.

The measured and numerically simulated chloride profiles are presented in Figs. 17-19. The upper and lower lines indicate the level of pessimistic and optimistic variations due to the positive and negative disparity, respectively, in input parameters including $\mathrm{D}_{\mathrm{nssm}}(+/-2 \times 23 \%$ as the reproducibility variation [6] for a confidence level of 95\%), the chloride concentration 
in sea water (assuming $+/-10 \%$ as the annual mean variation) and the exposure temperature (assuming $+/-1{ }^{\circ} \mathrm{C}$ as the annual mean variation). Figs. 17 and 18 show that the numerical simulations can predict the chloride profile with a high degree of accuracy. At the age of 18 years (Fig. 19), the simulation underestimates the chloride ion content at depths greater than $30 \mathrm{~mm}$; however, the data points are within the upper limit considered. It can be seen from Figs. 17-19 that the chloride ingress depth is strongly affected by the variations of the input parameters. A more precise service life design can be achieved by increasing the confidence in the input parameters. For example, by carrying out tests to determine $\mathrm{D}_{\text {nssm }}$ on concrete cured in same condition as the real structure.

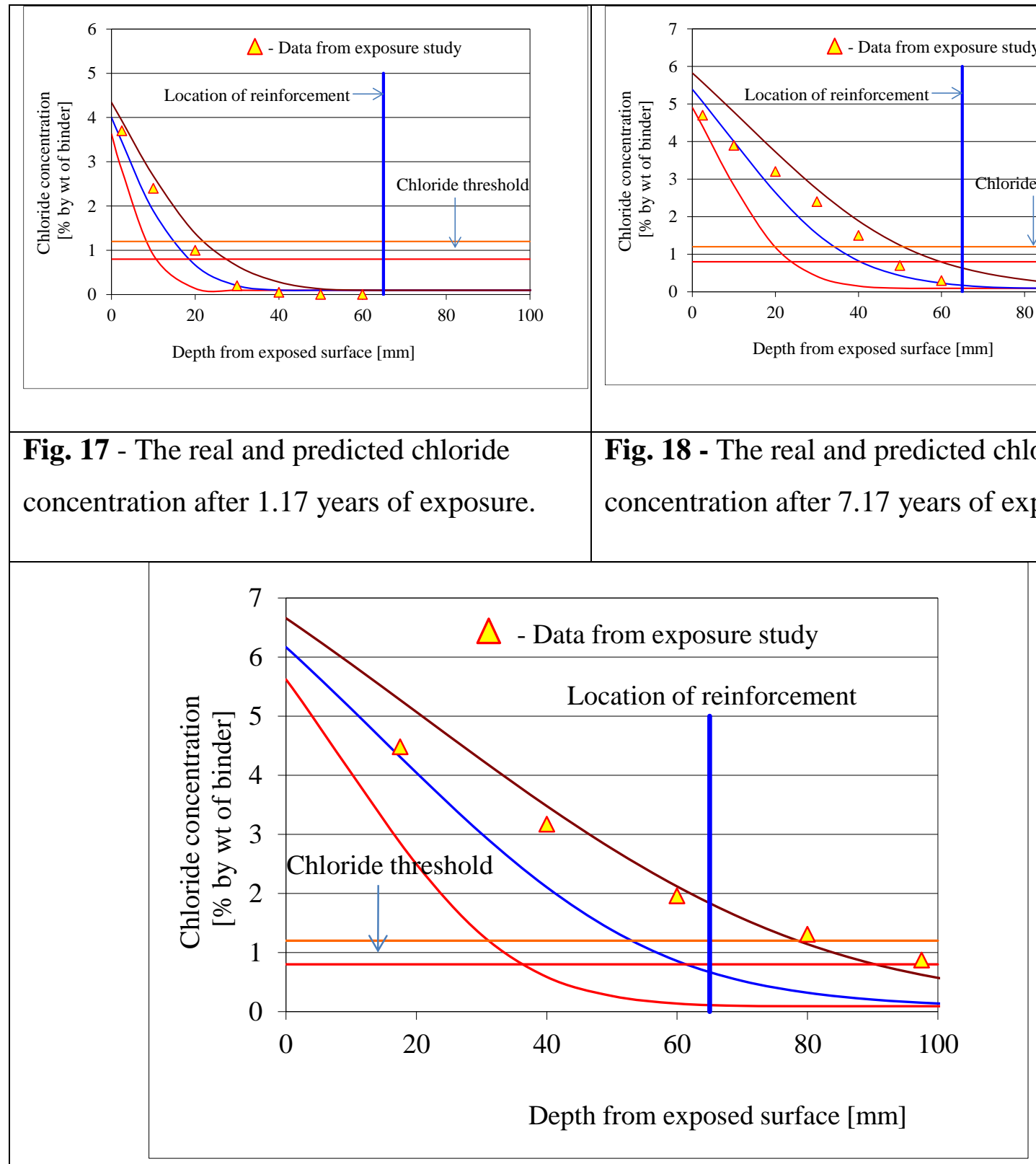

Fig. 19 - The real and predicted chloride concentration after 18 years of exposure. [Data 
Table 4. List of variables used in the ClinConc Model

\subsection{Guidelines for selecting concrete mixes for marine exposures}

Based on the non-steady state migration coefficient $\left(\mathrm{D}_{\mathrm{nssm}}\right)$ in Table 1 and ClinConc model that takes $D_{n s s m}$ as one of the input parameter, chloride profiles were simulated for the different concrete mixes exposed to the North Sea environment. Fig. 20 shows the chloride profiles after 50 years of exposure to tidal low-level (XS2 environment) exposure zone in North Sea. This will help to identify the suitability of mixes specified as per BS 8500 [20]. For XS2 environment, BS8500 allows $w / b$ of $\leq 0.55$, most cement combinations and a minimum binder content of $320 \mathrm{~kg} / \mathrm{m}^{3}$. Fig. 20 shows that even $0.5 \mathrm{w} / \mathrm{b}$ concrete studied here performs poorly in such environment. It is necessary, therefore, to undertake similar studies in order to identify the performance of concrete for various exposure environments and adoption of a performance-based approach in specifying concrete. Test results such as $\mathrm{D}_{\mathrm{nssm}}$ identified in Table 1 can be used in defining performance-based specifications for concretes. As an example, in order to keep the chloride concentration at the level of reinforcement that is at a depth of $50 \mathrm{~mm}$ from the exposure surface to a value below $0.5 \%$ by mass of binder, one could use the ggbs 0.42 concrete or, indeed, any concrete which has a diffusivity $\mathrm{D}_{\mathrm{nssm}}<$ $1 \times 10^{-12} \mathrm{~m}^{2} / \mathrm{s}$ at an age of 180days. The above guideline is conservative and only considers the time to corrosion initiation; the actual service life will depend on the corrosion propagation phase and the acceptable level of deterioration. 


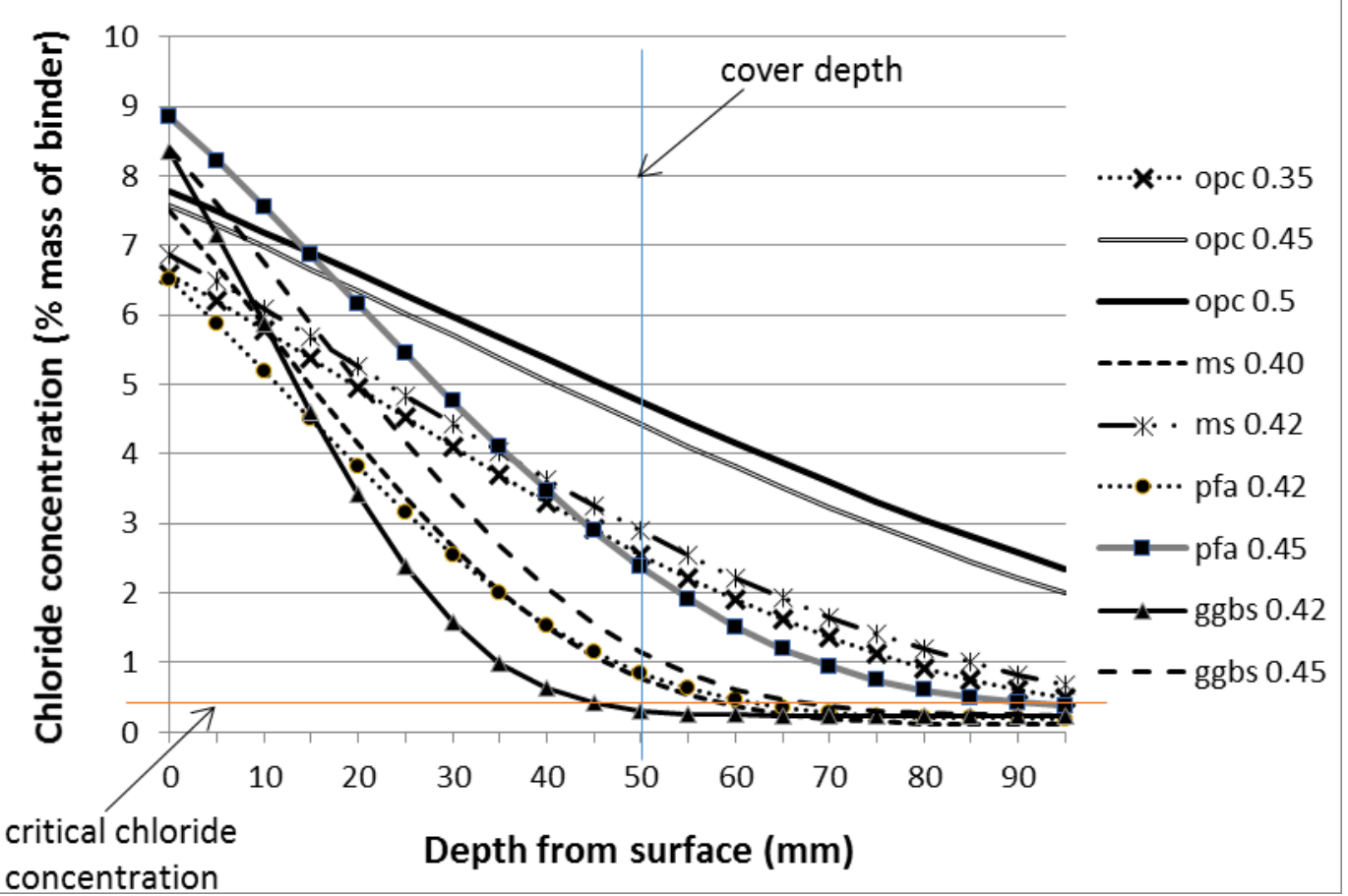

Fig. 20 - Numerically simulated chloride profiles for various concretes listed in Table 1 after 50 years to XS2 environment in North Sea.

\section{CONCLUDING REMARKS}

The applicability, scope and repeatability of various laboratory based test methods for assessing the chloride penetration resistance have been demonstrated. The validity of the Permit and Wenner resistivity test as on site methods for quantifying chloride transport in concrete was also established. It was identified that the use of the Permit eliminates the need for extracting concrete cores for the laboratory determination of the chloride diffusivity.

It was shown that the data from chloride testing can be used to predict the chloride concentration in a given exposure environment and at a given time through the use of a numerical simulation model. The accuracy of the prediction was also verified by comparing the predicted data against field data obtained from a long-term study. It was found that over the initial 7-years exposure the predicted and measured values were in good agreement; however, there was an underestimation of chloride content at depths $>30 \mathrm{~mm}$ at 18 years. This will require further refinement of the model. 
The combined use of testing and modelling for determining the long term performance of concretes was demonstrated and it should now be possible to adopt this approach to develop performance-based specification for concrete exposed to marine environments. Further challenges include, improving the accuracy of the model for later years, simplifying the modelling process and estimating the chloride threshold concentration that initiate corrosion.

\section{Acknowledgements}

The authors wish to acknowledge the Engineering and Physical Sciences Research Council, UK [EP/G025096, EP/G02152X] and EU Framework Programme 5 [GRD1-2002-71808] for the funding provided to carry out this research. The support and facilities provided by the Amphora NDT, the School of Planning, Architecture and Civil Engineering at Queen's University Belfast and the School of Energy, Geoscience, Infrastructure and Environment at Heriot-Watt University, Edinburgh are also appreciated.

\section{REFERENCES}

1. DuraCrete - Final technical report on Probabilistic performance based durability design of concrete structures, The European Union - Brite EuRam III project - BE95 -1347, May 2000, Pages [http://www.cur.nl/upload/documents/duracrete/BE1347R17.pdf], last accessed on June 2013.

2. Nganga, G., Alexander, M., Beushausen. H., Practical implementation of the durability index performance-based design approach, Construction and Building Materials, 2013, Vol. 45, August, pp. 251-261.

3. Alexander, M.G., Ballim, Y., Stanish, K.A., Framework for use of durability indexes in performance-based design and specifications for reinforced concrete structures, Materials and Structures, 2008; Vol. 41, Issue 5, pp. 921-936.

4. Muigai, R., Moyo, P., Alexander, M., Durability design of reinforced concrete structures: a comparison of the use of durability indexes in the deemed-to-satisfy approach and the full-probabilistic approach, Materials and Structures, 2012, Vol. 45, Issue 8, pp. 1233-1244. 
5. Polder, R.B., Wegen, G. van der, Breugel, K. van, Guideline for service life design of structural concrete - a performance based approach with regard to chloride induced corrosion, Proc. fib Workshop Performance-based Specifications for Concrete, Leipzig 14-15 June 2011, Eds. F. Dehn, H. Beushausen, pp. 25-34.

6. Chlortest- Resistance of concrete to chloride ingress-from laboratory test to in-field performance, CHLORTEST, Final Technical Report EU FP5 Growth Initiative (GRD1-2002-71808), 2006.

7. Nanukuttan, S.V., Development of a new test protocol for Permit ion migration test, Ph.D Thesis, Queen's University of Belfast, UK, pages 310, March 2007.

8. EPSRC, Development of a performance-based methodology for assessing concrete durability, funded by Engineering and Physical Science Research Council, EP/G02152X/1, 2009-2012. http://gow.epsrc.ac.uk/NGBOViewGrant.aspx?GrantRef=EP/G02152X/1 [Last accessed Nov 2014]

9. Nilsson, L.-O., Poulsen, E., Sandberg, P., Sorensen, H.E. and Klinghoffer, O., HETEK, Chloride penetration into concrete, state-of-the-art-, transport processes, corrosion initiation, test methods and prediction models, Report No. 53, pages 58, 1996.

10. NT BUILD 443, Concrete, Hardened: Accelerated Chloride Penetration, NORDTEST Method, 1995. http://www.nordtest.info/index.php/methods/building/item/concretehardened-accelerated-chloride-penetration-nt-build-443.html, [Last accessed Nov 2014].

11. Nordtest NT Build 492, Concrete, Mortar and Cement Based Repair Materials: Chloride Migration Coefficient from Non-steady State Migration Experiments, NORDTEST

Method,

1999.

http://www.nordtest.info/index.php/methods/building/item/concrete-mortar-andcement-based-repair-materials-chloride-migration-coefficient-from-non-steady-statemigration-experiments-nt-build-492.html?category_id=27, [Last accessed Nov 2014].

12. Andrade, C., Alonso, C., Arteaga, A. and Tanner, P, Methodology based on the electrical resistivity for the calculation of reinforcement service life, Fifth 
CANMET/ACI International Conference on Durability of Concrete, 2000, pp. 899915.

13. Castellote, M., Andrade, C. and Alonso, C., Measurement of the steady and nonsteady-state chloride diffusion coefficients in a migration test by means of monitoring the conductivity in the anolyte chamber, Comparison with natural diffusion tests, Cement and Concrete Research, Vol. 31, 2001, pp. 1411-1420.

14. Basheer, P.A.M., Andrews, R.J., Robinson, D.J. \& Long, A.E., 'PERMIT' ion migration test for measuring the chloride ion transport of concrete on site, NDT \& E International, vol. 38, no. 3, 2005, pp. 219-229.

15. Andrade, C., Calculation of chloride diffusion coefficients in concrete from ionic migration measurements, Cement and Concrete Research, Vol. 23, No. 3, 1993, pp.724-742.

16. Yang, C.C., Relationship between migration coefficient of chloride ions and charge passed in steady state, ACI Materials Journal, Vol. 101, No. 2, 2004, pp. 124-130.

17. Baroghel-Bouny, V., Kinomura, K., Thiery, M. and Moscardelli, S., (2010), Easy assessment of durability indicators for concretes with high volume of SCMs, $2^{\text {nd }}$ International Conference on Sustainable Construction Materials and Technologies, June 28-30, 2010, Web article, http://www.claisse.info/2010\%20papers/2010\%20Papers.htm [Last accessed 12 Nov 2014].

18. Polder, R.B., Test methods for on site measurement of resistivity of concrete - a RILEM TC-154 technical recommendation, Construction and Building Materials, Vol. 15, 2001, pp. 125-131.

19. ASTM C1202, Electrical Indication of Concrete's Ability to Resist Chloride Ion Penetration, Annual Book of American Society for Testing Materials Standards, 1997.

20. British Standard 8500-1:2006, Complementary British Standard to BS EN 206-1, Part 1 Method of specifying and guidance for the specifier, British Standard Institution (BSI), London, 2012. 
21. Nanukuttan, S.V., Basheer, L., McCarter, W.J., Robinson, D.J. and Basheer, P.A.M., Full-scale marine exposure tests on treated and untreated concretes: Initial seven year results, ACI Materials Journal, Vol. 105, No. 1, Jan-Feb 2008, pp. 81-87.

22. Tang, L., Service-life prediction based on the rapid migration test and the ClinConc model, Proceedings of International RILEM workshop on Performance Based Evaluation and Indicators for Concrete Durability, 19-21 March 2006, Madrid, RILEM PRO 47, pp. 157-164. 

Table 1 Details of concrete mixes (Quantities reported in $\mathrm{kg} / \mathrm{m}^{3}$ ) and their chloride ingress resistance as measured by different test methods

\begin{tabular}{|c|c|c|c|c|c|c|c|c|c|}
\hline Mix designation & opc 0.35 & opc 0.45 & opc 0.50 & ms 0.40 & ms 0.42 & pfa 0.42 & pfa 0.45 & ggbs 0.42 & ggbs 0.45 \\
\hline Country of Origin of cement & Sweden & Spain & \multicolumn{3}{|c|}{ Sweden } & Norway & Portugal & \multicolumn{2}{|c|}{ Netherlands } \\
\hline $\begin{array}{c}\text { Cement type } \\
\text { (BS EN 197-1, 2000) }\end{array}$ & $\begin{array}{l}\text { CEM I } \\
42.5 \mathrm{~N}\end{array}$ & CEM I-42.5 N & \multicolumn{3}{|c|}{ CEM I $42.5 \mathrm{~N}$} & $\begin{array}{c}\text { (18\% PFA) } \\
\text { CEM II/A-V } \\
42.5 \mathrm{R}\end{array}$ & $\begin{array}{l}(39 \% \text { PFA) } \\
\text { CEM IV/B } \\
32.5 \mathrm{R}\end{array}$ & \multicolumn{2}{|c|}{$\begin{array}{c}\text { ( 70\% Slag) CEM III/B } \\
42.5 \text { LH HS }\end{array}$} \\
\hline Cement content & 450 & 400 & 400 & 399 & 389.5 & 410 & 340 & 410 & 350 \\
\hline Microsilica & & & & 21 & 20.5 & & & & \\
\hline Water & 157.5 & 180 & 200 & 168 & 172.2 & 172.2 & 153 & 172.2 & 157.5 \\
\hline $\begin{array}{l}\text { Fine Aggregate } \\
\text { (Min size } 75 \mu \mathrm{m})\end{array}$ & $\begin{array}{c}904 \\
(\leq 8 \mathrm{~mm})\end{array}$ & $\begin{array}{c}742 \\
(\leq 6 \mathrm{~mm})\end{array}$ & $\begin{array}{c}920 \\
(\leq 8 \mathrm{~mm})\end{array}$ & $\begin{array}{c}842.5 \\
(\leq 8 \mathrm{~mm})\end{array}$ & $\begin{array}{c}897 \\
(\leq 8 \mathrm{~mm})\end{array}$ & $\begin{array}{c}901 \\
(\leq 8 \mathrm{~mm})\end{array}$ & $\begin{array}{c}62(\leq 2 \mathrm{~mm}) \\
603(2-4 \mathrm{~mm})\end{array}$ & $\begin{array}{c}901 \\
(\leq 8 \mathrm{~mm})\end{array}$ & $\begin{array}{c}70(\leq 1 \mathrm{~mm}) \\
790(1- \\
4 \mathrm{~mm})\end{array}$ \\
\hline Coarse Aggregate & $\begin{array}{l}904(5- \\
10 \mathrm{~mm})\end{array}$ & $\begin{array}{c}1030 \\
(6-16 \mathrm{~mm})\end{array}$ & $\begin{array}{c}816 \\
(5-10 \mathrm{~mm})\end{array}$ & $\begin{array}{c}842.5 \\
(8-16 \mathrm{~mm})\end{array}$ & $\begin{array}{c}897 \\
(10-15 \mathrm{~mm})\end{array}$ & $\begin{array}{c}901 \\
(10-15 \mathrm{~mm})\end{array}$ & $\begin{array}{c}619(4-12 \mathrm{~mm}) \\
555(12- \\
25 \mathrm{~mm})\end{array}$ & $\begin{array}{c}901 \\
(5-10 \mathrm{~mm})\end{array}$ & $\begin{array}{c}1040 \\
(4-16 \mathrm{~mm})\end{array}$ \\
\hline $\begin{array}{l}\text { Superplasticiser } \\
\% \text { of cement }\end{array}$ & $\begin{array}{l}\text { Cemflux } \\
\text { Bro } 1.0\end{array}$ & $\begin{array}{c}\text { Melcret } 222 \\
4.8\end{array}$ & - & $\begin{array}{l}\text { Cementa } \\
92 \mathrm{M} 3.4\end{array}$ & $\begin{array}{l}\text { CemFlux } \\
\text { Bro } 0.5\end{array}$ & $\begin{array}{c}\text { CemFlux Bro } \\
0.5\end{array}$ & $\begin{array}{l}\text { Rheobuild } \\
10004.1\end{array}$ & $\begin{array}{l}\text { CemFlux } \\
\text { Bro } 0.5\end{array}$ & $\begin{array}{c}\text { Cretoplast } \\
3.9\end{array}$ \\
\hline water/binder (w/b) & 0.35 & 0.45 & 0.5 & 0.4 & 0.42 & 0.42 & 0.45 & 0.42 & 0.45 \\
\hline Age at test (years) & $\sim 0.5$ & $\sim 1.0$ & $\sim 0.5$ & $>1.0$ & $\sim 0.5$ & $\sim 0.5$ & $<1.0$ & $\sim 0.5$ & $<1.0$ \\
\hline
\end{tabular}

Measurable performance indicators (chloride diffusivity/bulk electrical resistivity results) 


\begin{tabular}{|c|c|c|c|c|c|c|c|c|c|c|}
\hline \multicolumn{2}{|c|}{ Diffusivity/Resistivity } & opc 0.35 & opc 0.45 & opc 0.50 & ms 0.40 & $\mathrm{~ms} 0.42$ & pfa 0.42 & pfa 0.45 & ggbs 0.42 & ggbs 0.45 \\
\hline \multicolumn{2}{|c|}{$\begin{array}{c}\text { Dnssd } \times 10^{-12} \mathrm{~m}^{2} / \mathrm{s} \text { (standard } \\
\text { error) }\end{array}$} & $\begin{array}{l}5.11 \\
( \pm 0.56)\end{array}$ & $14.63( \pm 3.74)$ & $\begin{array}{l}16.56 \\
( \pm 1.82)\end{array}$ & $\begin{array}{l}1.61 \\
( \pm 0.62)\end{array}$ & $4.88( \pm 0.58)$ & $1.44( \pm 0.27)$ & $7.38( \pm 2.43)$ & $\begin{array}{l}1.31 \\
( \pm 0.16)\end{array}$ & $3.19( \pm 1.35)$ \\
\hline \multirow{2}{*}{$\begin{array}{c}\text { Chloride } \\
\text { concentration } \\
\text { (\% by mass of } \\
\text { binder) }\end{array}$} & $\begin{array}{l}\text { at } 5 \mathrm{~mm} \text { from } \\
\text { surface }\end{array}$ & 0.27 & 0.29 & 0.44 & 0.16 & 0.32 & 0.11 & 0.42 & 0.08 & 0.14 \\
\hline & $\begin{array}{c}\text { at } 10 \mathrm{~mm} \\
\text { from surface }\end{array}$ & 0.04 & 0.17 & 0.24 & - & 0.05 & - & 0.18 & 0 & 0.03 \\
\hline \multicolumn{2}{|c|}{$\begin{array}{c}\text { D nssm } \times 10^{-12} \mathrm{~m}^{2} / \mathrm{s} \text { (standard } \\
\text { error) }\end{array}$} & $\begin{array}{l}6.00 \\
( \pm 1.24)\end{array}$ & $15.00( \pm 3.02)$ & $\begin{array}{l}16.70 \\
( \pm 0.99)\end{array}$ & $\begin{array}{l}1.90 \\
( \pm 0.07)\end{array}$ & $6.90( \pm 0.50)$ & $1.70( \pm 0.13)$ & $3.70( \pm 0.54)$ & $\begin{array}{l}1.00 \\
( \pm 0.05)\end{array}$ & $2.20( \pm 0.25)$ \\
\hline \multicolumn{2}{|c|}{$\begin{array}{c}\text { Pbulk (ohm.m) } \\
\text { (standard error) }\end{array}$} & $176( \pm 16)$ & $\begin{array}{l}187 \\
( \pm 22)\end{array}$ & $\begin{array}{r}56 \\
( \pm 13)\end{array}$ & $\begin{array}{l}427 \\
( \pm 21)\end{array}$ & $\begin{array}{l}236 \\
( \pm 31)\end{array}$ & $\begin{array}{l}324 \\
( \pm 40)\end{array}$ & $\begin{array}{l}291 \\
( \pm 5)\end{array}$ & $838( \pm 160)$ & $\begin{array}{l}470 \\
( \pm 17)\end{array}$ \\
\hline
\end{tabular}

CemFlux Bro is polycarboxylether based superplasticiser; Melcret 222 and Rheobuild 1000 are both napthalene based superplasticisers; Cretoplast is a water reducing superplasticiser; Cementa $92 \mathrm{M}$ is melamine formaldehyde based superplasticiser; $D_{\text {nssd }}$ is the coefficient from non-steady diffusion test - NT Build 443; Dnssm is the coefficient from non-steady migration test - NT Build 492; $\rho$ bulk is the saturated bulk electrical resistivity - Andrade et al., (2000) 
Table 2. Details of mixes used in this experimental programme

\begin{tabular}{|c|c|c|c|c|c|c|c|c|c|}
\hline \multirow{3}{*}{$\begin{array}{c}\text { Mix } \\
\text { reference }\end{array}$} & \multirow[b]{3}{*}{$w / b$} & \multicolumn{6}{|c|}{ Mass of the ingredients $\mathrm{kg} / \mathrm{m}^{3}$} & \multirow{3}{*}{ 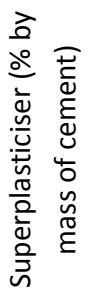 } & \multirow{3}{*}{ 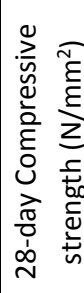 } \\
\hline & & \multirow[b]{2}{*}{ Water } & \multirow{2}{*}{$\begin{array}{c}\text { Portland } \\
\text { cement }\end{array}$} & \multirow{2}{*}{$\begin{array}{l}\text { Cement } \\
\text { replacements }\end{array}$} & \multicolumn{2}{|c|}{$\begin{array}{c}\text { Course } \\
\text { Aggregate }\end{array}$} & \multirow[b]{2}{*}{ sand } & & \\
\hline & & & & & $10 \mathrm{~mm}$ & $6 \mathrm{~mm}$ & & & \\
\hline 0.45 орс & 0.45 & 180.0 & 400.0 & 0 & 1030.0 & & 742.0 & & 34.5 \\
\hline $0.45 \mathrm{pfa}$ & 0.45 & 153.0 & 207.4 & 132.6 (pfa) & 1174.0 & & 665.0 & 3.4 & 28.0 \\
\hline $0.40 \mathrm{~ms}$ & 0.40 & 168.0 & 399.0 & 21.0 (ms) & 842.5 & & 842.5 & 3.4 & 35.5 \\
\hline 0.45 ggbs & 0.45 & 157.5 & 84.0 & 266.0 (ggbs) & 1040.0 & & 860.0 & 4.5 & 39.6 \\
\hline 0.52 орс & 0.52 & 208.0 & 399.9 & 0 & & 1199.7 & 659.9 & 0.9 & 21.0 \\
\hline $0.52 \mathrm{pfa}$ & 0.52 & 204.0 & 274.6 & 117.7 (pfa) & & 1176.7 & 647.2 & 0.9 & 13.0 \\
\hline $0.52 \mathrm{~ms}$ & 0.52 & 206.8 & 357.9 & 39.8 (ms) & & 1193.0 & 656.1 & 0.9 & 37.0 \\
\hline 0.52 ggbs & 0.52 & 206.7 & 198.8 & 198.8 (ggbs) & & 1192.7 & 656.0 & 0.9 & 21.0 \\
\hline
\end{tabular}

Note: $\quad \mathrm{w} / \mathrm{b}$ - water to binder ratio, ms- micro silica, pfa- pulverised fuel ash, ggbs- ground granulated blast furnace slag, SP - superplasticiser - Chemcrete S725; mixes with $\mathrm{w} / \mathrm{b} \leq 0.45$ was tested at 28 days (and 2 years), mixes with $\mathrm{w} / \mathrm{b} 0.52$ was tested at 56 days

Table 3. Mix details and test results for Dornoch pier stems

\begin{tabular}{|l|l|l|l|l|l|l|l|}
\hline Mix & Cement & $20 \mathrm{~mm}$ & $10 \mathrm{~mm}$ & Fines & Plasticiser & $\mathrm{w} / \mathrm{c}$ & $\mathrm{F}_{28}$ \\
& $\mathrm{~kg} / \mathrm{m}^{3}$ & $\mathrm{~kg} / \mathrm{m}^{3}$ & $\mathrm{~kg} / \mathrm{m}^{3}$ & $\mathrm{~kg} / \mathrm{m}^{3}$ & $\mathrm{~L} / \mathrm{m}^{3}$ & & $\mathrm{MPa}$ \\
\hline Plain & 460 & 700 & 350 & 700 & $3.60^{*}$ & 0.4 & 66 \\
& CEM I & & & & & & \\
& & & & & & & \\
\hline
\end{tabular}

* Sika FR 
Table 4. List of variables used in the ClinConc Model

\begin{tabular}{|c|c|c|c|c|c|c|}
\hline $\begin{array}{l}D_{\text {nssm }} \\
m^{2} / \mathrm{s}\end{array}$ & $\begin{array}{l}\text { Chloride } \\
\text { concentration } \\
\text { of sea water }\end{array}$ & $\begin{array}{l}\text { Air } \\
\text { Content }\end{array}$ & $\begin{array}{l}\mathrm{Na}_{2} \mathrm{O} \\
\text { equivalent }\end{array}$ & $\begin{array}{l}\text { Initial chloride } \\
\text { concentration }\end{array}$ & $\begin{array}{l}\text { Curing and } \\
\text { exposure } \\
\text { temperature }\end{array}$ & $\begin{array}{l}\text { Activation } \\
\text { Energy }\end{array}$ \\
\hline $\begin{array}{l}9( \pm 4.1) \times 10^{-12} \\
\text { (estimated } \\
\text { using Table } 1 \text { ) }\end{array}$ & $19.6 \mathrm{~g} / \mathrm{L}$ & $\begin{array}{l}3 \% \text { by } \\
\text { volume }\end{array}$ & $\begin{array}{l}0.41 \% \\
\text { Binder }\end{array}$ & $\begin{array}{l}0.05 \% \text { by mass } \\
\text { of binder }\end{array}$ & $\begin{array}{l}\text { Curing } 15 \circ \mathrm{C} \text { for first } \\
14 \text { days } \\
\text { Exposure }-10^{\circ} \mathrm{C} \\
\text { annual average }\end{array}$ & $\begin{array}{l}36000 \\
\mathrm{~J} / \mathrm{mol}\end{array}$ \\
\hline
\end{tabular}

\section{END OF DOCUMENT}

